\title{
The Value of Green Walls to Urban Biodiversity
}

Rebecca Collins $^{\mathrm{a}, 1}$, Marije Schaafsma ${ }^{\mathrm{b}}$, Malcolm D. Hudson ${ }^{\mathrm{a}}$

${ }^{a}$ Centre for Environmental Sciences, Faculty of Engineering and the Environment, University Road, University of Southampton SO17 1BJ, United Kingdom

${ }^{\mathrm{b}}$ Geography \& Environment, University Road, University of Southampton SO17 1BJ, United Kingdom

Email addresses: rc13g11@southamptonalumni.ac.uk (R. Collins), m.schaafsma@soton.ac.uk (M. Scaafsma), and mdh@soton.ac.uk (M. D.Hudson)

${ }^{1}$ Present address: Momentum Transport Planning, Clerkenwell House, 23 Hatton Wall, Farringdon, London, EC1N 8JJ, United Kingdom 


\section{The Value of Green Walls to Urban Biodiversity}

\section{Abstract}

Despite increased interest in the implementation of green walls in urban areas and the recognised benefits of monetary valuation of ecosystem services, no studies have been undertaken to estimate the economic value of biodiversity they provide. The valuation of natural resources allows policy makers to justify resource allocation. Using the Southampton, UK, as a case study, this paper estimates the public's perceived value of green walls to urban biodiversity, in the form of their willingness to pay (WTP). Estimates were derived using a random parameter model that accounted for socio-economic and attitudinal determinants of choice, using choice experiment data. Three green infrastructure policies were tested; two green wall designs ('living wall' and 'green façade') and an 'alternative green policy'; and compared against 'no green policy'. Results indicated a WTP associated with green infrastructure that increases biodiversity. Attitudinal characteristics such as knowledge of biodiversity and aesthetic opinion were significant, providing an indication of identifiable preferences between green policies and green wall designs. A higher level of utility was associated with the living wall, followed by the green façade. In both cases, the value of the green wall policies exceeds the estimated investment cost; so our results suggest that implementation would provide net economic benefits.

Key words: Green infrastructure, green wall, living wall, green façade, choice experiment 
Biodiversity has multiple roles in the delivery of ecosystem services: as a supporting service of other ecosystem services, as a final regulating ecosystem service in itself and as a good, such as the existence of an iconic species (Atkinson et al., 2012; Mace et al., 2012). Conserving biodiversity ensures the provision of ecosystem services and the multi-layered benefits that underpin human health and wellbeing (Bolund and Hunhammer, 1999; MEA, 2005; NEA, 2011). With increasing urbanisation, the role of urban biodiversity in delivering ecosystem services has been studied widely (Botzat et al., 2016). Ecosystem services are recognised to add value to urban environments in economic, social and environmental terms (Bolund and Hunhammer, 1999; Gómez-Baggethun and Barton, 2013; Natural England, 2013).

Biodiversity in cities is concentrated mostly within a limited network of green infrastructure (Finlay, 2010; Tzoulas et al., 2007). Conventionally, green infrastructure includes a combination of parks, gardens, green corridors and rivers, strategically planned and linked to protect biodiversity (Tzoulas et al., 2007). With current rates of urban development unlikely to decrease, existing green infrastructure is insufficient to prevent predicted declines in biodiversity in urban areas ( Mcdonald et al., 2008; Rozenweig, 2003). The adoption of additional green infrastructure is needed to ensure the continued provision of ecosystem services and safeguard the health and wellbeing of city dwellers (Francis and Lorimer, 2011; Tzoulas et al., 2007).

In cities and urban environments, where space is costly, an increasingly common approach to enhance green infrastructure is to integrate vegetation into vertical structures as 'green walls' (Chiquet et al., 2013; Francis and Lorimer, 2011; Manso and Castro-Gomes, 2015). The term green wall refers to all forms of vegetated vertical surfaces (Manso and Castro-Gomes, 2015; Weinmaster, 2009). Traditional green wall methods are historically known, dating back to the Hanging Gardens of Babylon, and the Roman and Greek Empires (Köhler, 2008; Weinmaster, 2009). New engineering and technological advances have resulted in a variety of designs that can be incorporated into new or existing infrastructure (Manso and Castro-Gomes, 2015; Weinmaster, 2009). At a local scale, green walls have proven benefits for biodiversity, with even simplistic flora ensemblages providing a habitat for invetebrates (e.g. Francis and Lorimer, 2011) and nesting, food and shelter resources for urban ornithology (e.g. Chiquet 
et al., 2013). Theoretically, advances in technology mean that living walls can be engineered to replicate natural habitats and create wider possibilities for biodiversity enhancement (Francis and Lorimer, 2001). Green walls can support biodiversity in cities at a landscape scale by acting as a "corridor" or "stepping stone" to facilitate movement and despersal (Angold et al., 2006). A well connected network, managed at a landscape scale, will increase the stability of urban biodiversity in the face of increased disturbances and stochastic changes (Goddard et al., 2010). The EU Green Infrastructure Policy, which is linked to the EU 2020 Biodiversity Strategy, recognises that connectivity is key for biodiversity resilience against change and further highlights green walls as an important, and cost effective, element of green infrastructure in the urban environment (EEA, 2011; European Commission, 2013).

The United Kingdom (UK) Government have formally recognised the importance of green infrastructure in the provision of biodiversity through the publication of the Natural Environment White Paper; The Natural Choice: Securing the Value of Nature (DEFRA, 2011). Informed by the findings of the UK National Ecosystem Assessment (NEA, 2011), the White Paper aims to halt biodiversity loss by 2020, support 'healthy and functioning ecosystems', and establish 'coherent ecological networks' (DEFRA, 2011). In the UK, decisions regarding the implementation of green walls, and other elements of green infrastructure, are made at a local and neighbourhood level, ${ }^{1}$ typically from an economic perspective (Vandermeulen et al., 2011). The monetary valuation of ecosystem services enables local authorities to quantify and recognise the benefits of ecosystem services, and justify the allocation of limited public resources (Natural England, 2013). The use of monetary indicators enables the direct comparison of alternative green policies as well as the costs based on a common unit of comparison, which is not always possible when using biological or descriptive indices (Natural England, 2013; Nijkamp et al., 2008; Nunes and Van den Bergh, 2001). Consequently, local authorities s and decision makers are calling for the assessment of green policies and infrastructure in economic terms (Natural England, 2013; PUSH, 2010).

\footnotetext{
${ }^{1}$ The Localism Act 2011, and the National Planning Policy Framework (DCLG, 2012), led to fundamental changes in the planning system; power has shifted to local and neighbourhood levels. Subsequently, it is now the decision of local authorities to implement a green infrastructure policy.
} 
To date, there have been two studies that quantify benefits of green walls. The first, a study by Veistan et al. (2012), successfully provided an economic unit of acoustic and aesthetic benefits. The second, a study by Perini and Rosasco (2013), presents a cost-benefit anaylsis to determine the economic sustainability of green walls; the benefits of biodiversity where included within the scope of their analysis but were only considered at a qualitative level. Neither study specifically quantified the benefits of biodiversity provided by green walls and cannot reliably be used to justify the implementation of green walls as a means to enhance biodiversity. Therefore, the aim of this paper is to present a monetary valuation study of green infrastructure; in which we set out to economically quantify the value of biodiversity provided by green walls, and determine public preferences towards green wall design.

\subsection{Environmental Valuation Methodology}

\subsection{Application of Choice Experiments to value biodiversity}

For many benefits generated by biodiversity there is no formal market, i.e. the value is non-marketed (Jones-Walters and Mulder, 2009), and analysts wishing to value such benefits have to rely upon non-marketed valuation techniques (Bartkowski et al., 2015). Among the array of tools and methods to monetise non-market values, the recently more commonly adopted technique is choice experiments (CEs) (Bartkowski et al., 2015). Developed by Louviere and Hensher (1982) and Louviere and Woodworth (1983), CEs involve the application of characteristics theory of value (Lancaster, 1966), combined with random utility theory (Manski, 1977; Thurstone, 1994), where utility refers to the total amount of satisfaction received from consuming a good or service (Louviere et al., 2000). CEs rely on the generation and analysis of stated preference data; data are acquired through questionnaires (Hoyos, 2010). Respondents, usually the general public, are presented with choice sets containing mutually exclusive hypothetical alternatives and asked to choose their preferred option (ibid.). Alternative choices are defined and differentiated by a set of attributes, each attribute taking more than one level. The individual's choice implies a trade-off between alternatives (Hanley et al., 2002; Hoyos, 2010). When cost or price is included as an attribute, marginal utility estimates can be obtained and converted into willingness to pay (WTP), thus providing a monetary value (Bartkowski et al., 2015; Jones-Walters and Mulder, 2009). The 
application of a CE also presents the opportunity to gauge public preferences for different policy designs, and assess whether these preferences vary with individual characteristics (Nijkamp et al., 2008; Vandermeulen et al., 2011).

Due to the non-market value of urban biodiversity, the use of hypothetical markets in CEs justifies the use of stated preference method in this study (Gómez-Baggethun and Barton, 2013). Other methods do not have the potential to capture non-use (Pascual et al., 2010) and indirect values, which are crucial value components of biodiversity (Bartkowski et al., 2015). Existing studies valuing the benefits of biodiversity include Christie et al. (2004; 2006), Morse-Jones et al. (2012) and Garrod and Willis (1997). There are also a number of studies utilising CEs to value the benefits of other elements of green infrastructure in urban areas including; urban forests (Bernath and Roschewitz, 2008; Kwak et al., 2003), wetlands (Boyer and Polasky, 2004), open spaces (Brander and Koetse, 2011) and urban greenways (Lindsey and Knaap, 1999).

Biodiversity is a complex and multi-level concept that can be broken down into many additional attributes (Bartkowski et al., 2015). One of the critiques of monetary valuation of biodiversity is that respondents may interpret this concept (and associated benefits) differently. Biodiversity can be defined at the level of genes, species, ecosystems or functions (Nunes and Van den Bergh, 2001), but the term is also used more broadly to refer to biological variety in the environment at all levels, indicated by the number of different species of plants and animals and habitats present. These multiple roles are associated with multiple benefits (and multiple beneficiaries), which makes monetary valuation of biodiversity challenging (Atkinson et al., 2012), especially when the processes and functions leading to benefits are interdependent and nonlinear. One option would be to list all such benefits in non-monetary terms, but knowledge about the range and amount of such benefits may not exist and it would greatly complicate the decisions faced by respondents in the CE. In general, high complexity can negatively influence the validity and reliability of estimates (Hanley et al., 2002) and has been attributed to the current limited use of CEs in day-to-day decision making, particularly at a local planning level (Broekx et al., 2013). 
The debate on the appropriateness and reliability of monetary valuation is on-going. Arguments in favour include practical requests for value estimates (e.g. Rudd et al., 2016), the need to demonstrate the importance of biodiversity for green economic development (e.g. Potschin et al., 2016), and the possibility of approximating of public support expressed in monetary terms and comparison with costs that can be valid in particular contexts (e.g. Lienhoop et al., 2015). However, others argue that stated preference techniques are not sufficiently reliable to be used for monetary valuation when respondents have no clear conceptual understanding of the complexity of the good they are asked to value (e.g. Farnsworth et al., 2015), or are uncertain of their response (e.g. Ready et al., 2001). Likewise, when respondents do not consider the scenario to be consequential, stated WTP results may be biased (Carson and Groves, 2007; Jones-Walters and Mulder, 2009). Respondents who concentrate on the payment vehicle rather than on the desirable quality of the service provided may provide conservative estimates (e.g. Carson and Groves, 2007). Responding to concerns about hypothetical bias, many studies have compared revealed and stated preference data and found similarities in preference structures (Adamowicz et al., 1994; Boxhall et al., 1996; Jones-Walters and Mulder, 2009). Finally, some authors raise an ethical argument against the reduction of the multiple values into a single numeraire that may ignore the intrinsic or moral value of a species existence (e.g. Edwards and Abivardi 1998; Hanley and Milne 1996). We take a pragmatic approach here, and argue that the benefits of valuation outweigh those of the objections (Nijkamp et al., 2008) and seek to develop policy-relevant monetary values for cost-benefit analysis, using a broader definition of biodiversity (focusing only on a single attribute level of biodiversity), with the qualification that the results should be interpreted as providing only one, and an incomplete, account of public values for biodiversity (Nunes and Van den Bergh, 2001).

\subsection{Choice modelling theory}

The analysis of choices made in the CE is based on McFadden's (1974) random utility model; where the utility function U can be separated into an observable systematic component $\mathrm{V}$, and an unobservable error component $\varepsilon$ (Hoyos, 2010). Hence;

$$
\mathrm{U}_{\mathrm{int}}=\mathrm{V}_{\mathrm{int}}+\varepsilon_{\mathrm{int}}
$$


where, $U_{\text {int }}$ is respondent $n^{\prime}$ s utility of choosing option $\mathrm{i}\left(\mathrm{i}=1,2, \ldots, \mathrm{i}^{\text {th }}\right)$ in choice situation $\mathrm{t}\left(\mathrm{t}=1,2,3, \ldots \mathrm{t}^{\text {th }}\right)$. It is assumed that alternative $\mathrm{i}$ is chosen over alternative $\mathrm{j}$ if $U_{\text {int }}>U_{j n t}$. The error term $\varepsilon$ includes all unobserved variables that impact the utility of choosing a specific alternative. The observable component of utility can be expressed as two additive parts;

$$
\mathrm{V}_{\mathrm{int}}=\alpha_{\mathrm{in}}+\beta_{\mathrm{kn}} \mathrm{X}_{\mathrm{int}}
$$

where $\alpha_{\text {in }}$ is the alternative specific constant capturing the intrinsic preference for a choice alternative over and above the baseline. The $\beta$-terms are parameters to be estimated; $\beta_{\mathrm{kn}}$ reflects the preference parameters related to the attributes $(\mathrm{k})$ in set $\mathrm{X}$, therefore, $\mathrm{X}_{\mathrm{int}}$ is a vector of observed attributes. To account for explanatory variables such as respondent and attitudinal characteristics, the observable component can be further expressed as;

$$
V_{\text {int }}=\alpha_{\text {in }}+\beta_{\text {kn }} X_{\text {int }}+\gamma_{\mathrm{i}} s_{n}
$$

in this case, $\gamma_{\mathrm{i}} \mathrm{s}_{\mathrm{n}}$ captures systematic preference heterogeneity as a function of individual characteristics $\left(\mathrm{s}_{\mathrm{n}}\right)$. Thus creating a linear combination of observed and explanatory variables, specified as follows:

$$
\mathrm{U}_{\mathrm{int}}=\alpha_{\mathrm{in}}+\beta_{\mathrm{n}} \mathrm{X}+\gamma_{\mathrm{i}} \mathrm{s}_{\mathrm{n}}+\varepsilon_{\mathrm{int}}
$$

Eq. (4) represents a basic conditional logit model with socio-economic characteristics.

However, estimates derived by the conditional logit model are criticised for not reflecting realistic situations (Hoyos, 2010; Train, 2003), because they do not represent random taste variations (i.e. those that cannot be linked to observed characteristics of the respondents). Moreover, conditional logit models are constrained by the independence of irrelevant alternatives (IIA) hypothesis which states that the relative probabilities of two options being selected is unaffected by the introduction of removal of other alternatives; i.e. probability of choosing alternative $\mathrm{i}$ over alternative $\mathrm{j}$ should not depend on whether some other alternative $\mathrm{k}$ is present or absent. In cases where the IIA hypothesis is violated, mixed logit models including random parameters can be estimated to account for taste heterogeneity in a population (Hoyos, 2010). Under the mixed model approach, the unobserved portion of utility is partitioned into two additive terms: 


$$
\mathrm{U}_{\mathrm{int}}=\alpha_{\mathrm{in}}+\beta_{\mathrm{n}} \mathrm{X}+\gamma_{\mathrm{i}} \mathrm{s}_{\mathrm{n}}+\varepsilon_{\mathrm{int}}+\eta_{\mathrm{in}}
$$

The first term, $\varepsilon$ is an unobservable error component of utility that is assumed to be an identically and independently distributed standard Gumbel distribution term. The second, $\eta$ is the idiosyncratic random error-component, which enters the utility function of the hypothetical alternatives. The integral of Eq. (5) cannot be evaluated analytically and simulation maximum likelihood methods are used to estimate the mixed models (Train, 1999).

\section{Methods}

\subsection{Study area}

The research reported in this paper is based on data obtained from the City of Southampton, Hampshire, on the south coast of England. Southampton is the largest city in Hampshire with a population of approximately 250,000 people (SCC, 2015), and a population density of 4,858 people per square kilometre (ONS, 2013), the second highest population density outside of London (ONS, 2013). Characteristically for urban areas, green infrastructure within Southampton is limited and scattered throughout the city, with several elements of high natural environment quality, such as; Southampton Common, Central Parks, the Greenways Network, Waterside, and the internationally important River Itchen and River Test (SCC, 2008). All of these types of green infrastructure provide habitats for a diverse range of species, and are proven to support urban populations of protected species such as; bats, badgers, great crested newts and slow worms (Hand and Barker, n.d.). Southampton City Council owns and manages the majority of open spaces with special biodiversity interests, granting access to nature for urban residents (ibid.).

As part of the Partnership for Urban South Hampshire (PUSH, 2010), Southampton City Council (SCC) officially recognised the importance of biodiversity and is considering implementing green walls into the city centre to improve connectivity of the city's existing green infrastructure network (SCC, 2008). At present, there are few green walls scattered throughout the city, including; modular wall designs at University of Southampton halls of residence City Gate Way, and at a SCC building One Guildhall Square.

The green wall at One Guildhall Square forms part of the Southampton City Centre Master Plan as a strategy to create a greener city centre (David Lock Associates, 2013). 
Southampton's high population density and characteristic green infrastructure network combined with SCC's interest in the adoption of green walls makes the city an ideal case study for this CE as a representation of other urban environments.

\subsection{Attribute selection and choice design}

The first step of a CE is to identify choice alternatives and their attributes. Four policies were identified and were described in the simplest terms possible (Table 1). Two green wall policies, a living wall and a green façade, were both deemed necessary inclusions in the choice experiment due to their contrasting aesthetic difference that may influence preferences. Green façades are based on the traditional approach to vertical greening, and involve the colonisation of woody or herbaceous climbing plants, rooted either to the ground or to elevated planter boxes, on a vertical surface such as a wall or trellis (Chiquet et al., 2013). Façades are therefore restricted in the variety of species they can support (Köhler, 2008; Manso and Castro-Gomes, 2015). Living walls, also referred to as modular green walls, are a more recent innovation and represent a more complex approach to vertical greening (Köhler, 2008). Formed from a modular system of planter boxes (or a similar structure containing a growing medium), often with an integrated water delivery and drainage system, living walls can support a wide variety of plants that can be anchored at any height (Francis and Lorimer, 2011). This enables the rapid and uniform coverage of a vertical surface (Köhler, 2008; Manso and Castro-Gomes, 2015).

Despite potential implications on biodiversity at a landscape scale, the descriptions presented to respondents for the green wall policies focussed on the impact the two designs had on urban plant biodiversity (Table 1). This follows findings from previous research that city dwellers generally have poor biodiversity identification skills and are better able to estimate plant biodiversity than the biodiversity of other taxa (Fuller et al., 2007; Shwartz et al., 2015). An alternative green policy was formulated and included as an opportunity for respondents to reject the two green wall policies but still choose to enhance urban biodiversity. The fourth option, labelled 'no green policy', enabled respondents to not fund any of the three additional 'green policies'. 
Table 1. Policy choice alternatives and descriptions presented to respondents in the CE

\begin{tabular}{ll}
\hline Policy & Policy description \\
\hline Living wall & $\begin{array}{l}\text { Walls contain a soil like substance and can support a large number } \\
\text { (more than three) of different plants growing at any height. }\end{array}$ \\
Green façade & $\begin{array}{l}\text { Made up of one or two climbing plants growing up an existing vertical } \\
\text { surface. }\end{array}$ \\
Alternative green policy & $\begin{array}{l}\text { Investment into existing green and open spaces. Limit the } \\
\text { enhancement of biodiversity to areas already supporting some level of } \\
\text { biodiversity. }\end{array}$ \\
No implementation of a new green policy to enhance urban \\
biodiversity. Allow existing policies and/or strategies to continue and \\
urban biodiversity to continue to decline.
\end{tabular}

To ensure the simplicity of choice options, only two attributes were included; biodiversity and cost. The biodiversity attribute level varied according to plausible levels

(Table 2), i.e. the three 'green' policies do not result in a decline in biodiversity and 'no green wall' does not result in an increase in biodiversity.

The associated cost levels were defined according to the estimated cost to implement a green wall; approximately $f 5$ to $f 13$ per household per year for a living wall and $f 2$ per household for a green façade. ${ }^{2}$ The highest cost level of $£ 25$ represents any additional benefits obtained from the green wall policy. The survey included two versions of the fourth 'No green policy' alternative: either a zero payment in which biodiversity would decline, or a small payment of $f 2$ in which the decline of biodiversity would be slowed down.

\footnotetext{
${ }^{2}$ These cost estimates are based on the assumptions that living walls costs between $f 750$ to $f 2,000$ per square metre, and green façades approximately $f 280$ per square metre (Growing Green Guide, 2013), that the green wall proposed is 120 metres long and 5 metres high, and a population of 91,217 households in Southampton (SCC, 2008). The proposed dimensions of the green wall were not used for survey purposes following feedback from the pilot survey.
} 
Table 2. Policy attributes and their levels

\begin{tabular}{|c|c|c|}
\hline Choice alternative & Attribute & Levels \\
\hline \multirow[t]{5}{*}{ Living wall } & Urban Biodiversity & Increase biodiversity \\
\hline & & Maintain biodiversity \\
\hline & Cost & $£ 2$ per household per year \\
\hline & & f10 per household per year \\
\hline & & £25 per household per year \\
\hline \multirow[t]{5}{*}{ Green façade } & Urban Biodiversity & Increase biodiversity \\
\hline & & Maintain biodiversity \\
\hline & Cost & £2 per household per year \\
\hline & & f10 per household per year \\
\hline & & £25 per household per year \\
\hline \multirow[t]{5}{*}{ Alternative green policy } & Urban Biodiversity & Increase biodiversity \\
\hline & & Maintain biodiversity \\
\hline & Cost & $£ 2$ per household per year \\
\hline & & f10 per household per year \\
\hline & & f25 per household per year \\
\hline \multirow[t]{4}{*}{ No green policy } & Urban Biodiversity & Slow biodiversity decline \\
\hline & & Allow biodiversity decline \\
\hline & Cost & f0 per household per year \\
\hline & & £2 per household per year \\
\hline
\end{tabular}

Attributes and levels were combined using SPSS Orthoplan to construct an orthogonal, fractional factorial main-effects design. Fractional factorial designs permit the statistical testing of several factors, without testing every combination of factor levels (Hoyos, 2010). The final design resulted in the formation of 16 unique choice sets split over two blocks, i.e. each respondent was asked to make eight choices. The text of an example choice card is included in Table $3-$ the original choice cards contained example photographs of the structures.

Table 3. An example choice set

\begin{tabular}{|c|c|c|c|c|}
\hline Policy option & Living wall & Green façade & Alternative green policy & No green policy \\
\hline Biodiversity & $\begin{array}{l}\text { Increase level of urban } \\
\text { biodiversity }\end{array}$ & $\begin{array}{l}\text { Maintain level of urban } \\
\text { biodiversity }\end{array}$ & $\begin{array}{l}\text { Maintain urban biodiversity at } \\
\text { current level }\end{array}$ & $\begin{array}{l}\text { Allow urban biodiversity to } \\
\text { decline }\end{array}$ \\
\hline Cost & $f 25$ & $£ 10$ & $f 10$ & fo \\
\hline
\end{tabular}




\subsection{Data collection and analysis}

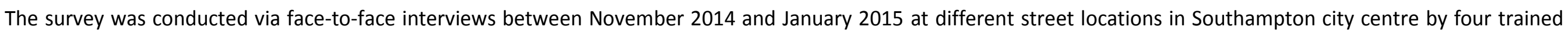

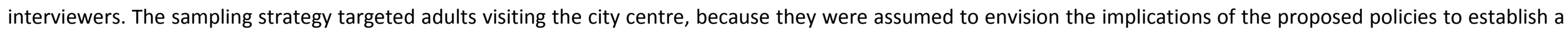

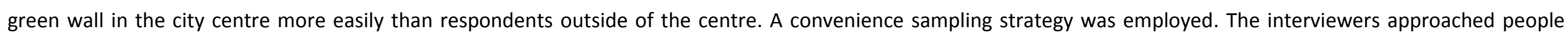

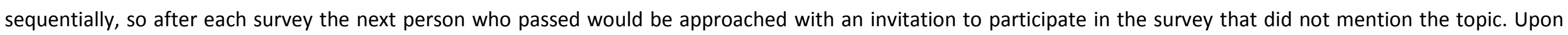

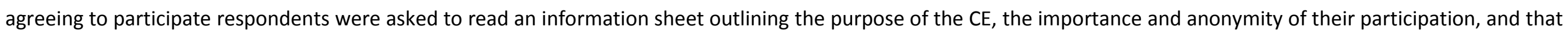

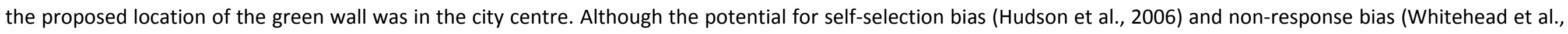

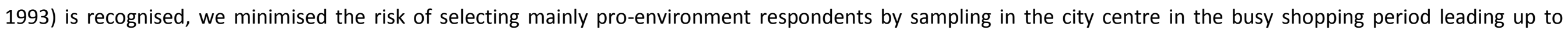

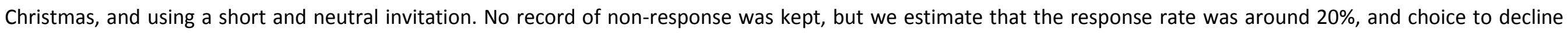
participation was made before the topic of the survey was mentioned.

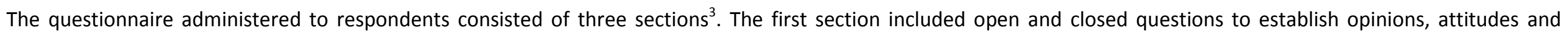

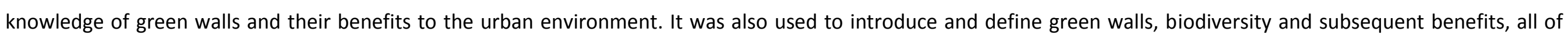

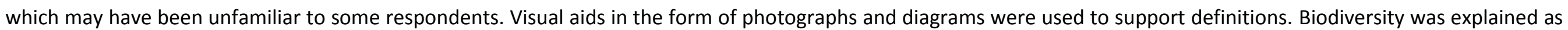

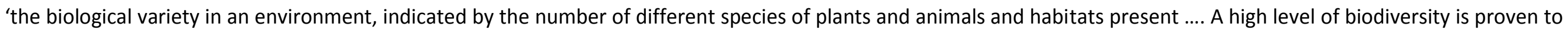

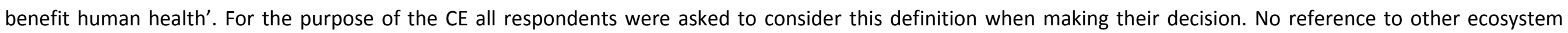

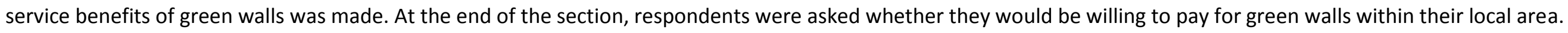

\footnotetext{
${ }^{3}$ Questionnaire provided in the appendix
} 
The second section was the CE exercise; the policy options, the attributes, and the cost of policy implementation were described to the respondents. It was explained that the cost would be a reoccurring annual payment covered through a budget reallocation decision made by the council, which would amount to $\mathrm{X}$ amount of their annual Council Tax bill. During the pilot study, this payment vehicle was tested using various descriptions to ensure understanding was clear. It was emphasised to participants that as a budget reallocation other policies currently receiving funding through their Council Tax would undergo a cut to account for their decision, and that choosing a lower cost scheme would translate into them wanting less of their Council Tax allocated to the proposed policies. Participants were presented with examples of services funded by SCC and asked to consider these services, or services they know to be SCC funded, when making their decision. This "bundle" approach to budget reallocation is consistent with the payment vehicles adopted in previous studies (e.g. Bergstrom et al., 2004; Swallow and McGonagle, 2006). By bundling all services together respondents are making a trade-off between more green policies, and less of all other public services. Respondents were then randomly allocated a version (block) of the choice sets and asked to select their preferred policy from each of the eight choice cards, where they were reminded to consider the policy design, impact on biodiversity and differing cost when making their choice. The third and final section included questions to collect socioeconomic data. All definitions and descriptions used in the final questionnaire were refined based upon feedback from nine respondents in a pilot study. Feedback indicated that the structure of the questionnaire was clear, but definitions for both biodiversity and green walls needed to be simplified and more pictorial evidence was recommended.

Data was analysed using the R software (version 3.1.2). Both mixed and conditional logit models were estimated. Mixed logit models were simulated using Halton draws with 1000 replications. The parameter estimates from the models were used to obtain marginal WTP for selected attributes using the following formula;

$$
\mathrm{WTP}=\frac{\beta_{\text {Attribute }}}{\beta_{\mathrm{M}}}
$$

where $\beta_{\text {Attribute }}$ is the coefficient on the attribute of interest and $\beta_{M}$ is the negative coefficient of the cost variable. The ninety-five percent confidence intervals around the mean WTP values were then estimated using Krinsky and Robb (1986) bootstrapping procedures with 2000 draws. 


\section{Results}

\subsection{Sample statistics}

A sample totalling 127 respondents completed the survey, each representing a different household. There were an additional 23 partially completed surveys (because of time constraints or aversion to provide socio-economic data), all of which were disregarded. None of the participants objected to the payment vehicle or any other part of the hypothetical scenario.

The sample population was made up of $44 \%$ males, and had modal education level of greater than or equal to level 4 of the European Qualification Framework (EC, 2016). The largest proportion of respondents were in full time employment (43\%). The socio-demographic characteristics of the sample population were compared to the Southampton population (Table 4), using both 2011 census data (ONS, 2011) and 2014 annual survey data (ONS, 2014), where available. Analysis suggests that the sample is mostly representative of the Southampton population, conforming to the census population for both age (Chi-squared test; $\chi^{2}=10.275$, d.f. $=5$, $\left.P=0.068\right)$ and gender (Chisquared test; $\chi^{2}=2.036$, d.f.= $\left.1, P=0.154\right)$. However, the sample population has a greater representation of people with qualifications greater than level 4 compared to the census data, and a lower representation of people with no qualifications (Chi-squared test; $\chi^{2}=391$, d.f. $=5, P<0.001$ ). This is likely to a be a result of a slight overrepresentation of the student population within the sample, in addition to a slight underrepresentation of the unemployed $\left(\right.$ Chi-squared test; $\chi^{2}=42.775$, d.f. $=4$, $\mathrm{P}<0.001)$.

Examination of attitudinal characteristics (Table 5 ) indicated that just under half of the sample population $(n=70)$ knew what a green wall was prior to completing the CE. The remaining 57 respondents were unfamiliar with the design concept; despite this, approximately $86 \%$ of those unfamiliar with green walls still found them to be aesthetically pleasing when presented with the images used in the CE. 

Table 4. Socio-demographic characteristics of respondents/ household

\begin{tabular}{|c|c|c|}
\hline Characteristic & Percentage of sample population & Percentage of Southampton population \\
\hline \multicolumn{3}{|l|}{ Age: } \\
\hline $18-24$ & 28 & 21 \\
\hline $25-34$ & 28 & 21 \\
\hline $35-44$ & 14 & 16 \\
\hline $45-54$ & 14 & 14 \\
\hline $55-64$ & 2 & 11 \\
\hline $65+$ & 14 & 17 \\
\hline \multicolumn{3}{|l|}{ Gender: } \\
\hline Male & 44 & 50 \\
\hline \multicolumn{3}{|l|}{ Qualification attainment: ${ }^{1}$} \\
\hline No qualifications & 0 & 7 \\
\hline Level 1 & 12 & 10 \\
\hline Level 2 & 17 & 16 \\
\hline Level 3 & 14 & 25 \\
\hline$\geq$ Level 4 & 56 & 34 \\
\hline Other & 1 & 8 \\
\hline \multicolumn{3}{|l|}{ Employment status: } \\
\hline Full time employment & 43 & 40 \\
\hline Part time employment & 14 & 17 \\
\hline Unemployed & 4 & 15 \\
\hline Student & 35 & 11 \\
\hline Retired & 4 & 16 \\
\hline \multicolumn{3}{|l|}{ Annual household income: ${ }^{2}$} \\
\hline$<£ 20,000$ & 26 & N/A \\
\hline$£ 20,000-£ 40,000$ & 20 & N/A \\
\hline$f 40,000-f 60,000$ & 26 & N/A \\
\hline$£ 60,000-£ 80,000$ & 12 & N/A \\
\hline$£ 80,000-£ 100,000$ & 6 & N/A \\
\hline$>£ 100,000$ & 2 & N/A \\
\hline Prefer not to say & 8 & N/A \\
\hline
\end{tabular}

Notes: ${ }^{1}$ Southampton population figures from 2014 data. All other figures from 2011 data.

${ }^{2}$ Categorical data for household income was not available from the census. Median gross weekly earnings to be $£ 401$ per resident in employment (CI\%=干3.9) (ONS, 2014). Extrapolating this across the year provides gross annual earnings of $£ 20,852$ per resident in employment. Although this value falls within the median category of the sample population (median $=2.5, S . E=\mp 0.10$ ), the two cannot be accurately compared as underlying assumptions regarding household structure would have to be made. 
A total of 115 respondents found green walls to be aesthetically pleasing, the remaining 12 respondents were either unsure or did not find green walls aesthetically pleasing. In the $\mathrm{CE}$, all 115 respondents who found green walls to be aesthetically pleasing did select a preferred green wall design; with 81 respondents selecting the living wall, and the remaining 34 preferring the green façade.

Only $6 \%$ of choices in the CE were for the no-change option (no payment into green infrastructure, continued biodiversity decline). Finally, 68 respondents were aware of at least one benefit of green walls in cities and 97 of all respondents said to be familiar with the term biodiversity, subsequently understanding of this term was generally not found to be a limiting factor in this CE.

Table 5. Attitudinal characteristics of respondents/respondents household

\begin{tabular}{lll}
\hline Attitudinal characteristic & Number of respondents & Percentage of respondents \\
\hline $\begin{array}{l}\text { Know what a green wall is: } \\
\text { Yes }\end{array}$ & 70 & 55 \\
Find green walls aesthetically pleasing: & 115 & 91 \\
$\quad$ Yes & & 68 \\
Design preference: & 86 & 28 \\
$\quad$ Modular green wall & 36 & 4 \\
$\quad$ Green façade & 5 & 54 \\
$\quad$ Neither & 68 & 76 \\
Aware of benefits green walls may provide: & 97 & \\
$\quad$ Yes & & \\
Familiar with the term biodiversity: &
\end{tabular}

\subsection{Model estimates}


Two generic model specifications were estimated: an attributes-only model (Model A) and a model including individual-specific variables interacted with the policy options

(Model B). Results of the Hausman-McFadden test (1984) led to reject the IIA assumption for both specifications of the conditional logit models. Here we present the estimates of the best fit mixed logit models, according to the Log likelihood and Akaike Information Criterion (AIC) (Table 6).

Both models were significant according to the results of the Likelihood ratio test ( $P>0.001$, in both cases). As many of the attributes are categorical, the model includes dummy variables: three for the different policy options using no green wall as the baseline, and two for biodiversity. Because of the design restrictions, the level "maintain biodiversity" is the baseline for the green policies against which the parameter of biodiversity increase should be compared, and the "decline in biodiversity" is the baseline against which the parameter of the "slow decline" can be interpreted for the no-green policy options. For the two biodiversity variables and the living wall options, random parameters were estimated, indicating that there is significant unexplained preference heterogeneity among the respondents in the sample. For the other two options (green façade and alternative policy), taste heterogeneity was not statistically significant. The cost attribute is a numerical variable, for which a fixed parameter is estimated.

Table 6. Choice model estimates

\begin{tabular}{lll}
\hline Attribute & Mixed logit Models & \\
\cline { 2 - 3 } & Model A & Model B \\
\hline Policy characteristics: fixed effects & $1.977^{* * *}(5.92)$ & $1.084^{*}(1.94)$ \\
Green façade & $1.592^{* * *}(4.77)$ & $1.608^{* * *}(4.88)$ \\
Alternative policy & $-0.061^{* * *}(-4.93)$ & $-0.061^{* * *}(-4.93)$ \\
$\quad$ Cost & & $0.588^{* *}(2.24)$ \\
Policy characteristics: random effects & $1.094^{* * *}(6.37)$ & $0.999^{* * *}(5.75)$ \\
Increase biodiversity & $1.071^{* * *}(6.00)$ & $1.309^{* *}(2.38)$ \\
(s.d. normal distribution) & $2.195^{* * *}(6.41)$ & $0.658^{* * *}(4.21)$ \\
Living wall & $0.696^{* * *}(4.57)$ & $-2.925^{* * *}(2.60)$ \\
(s.d. normal distribution) & $-3.038^{* *}(2.47)$ & $3.188^{* * *}(4.34)$ \\
Slowing biodiversity decline & $3.413^{* * *}(4.03)$ & $0.672^{* *}(2.31)$ \\
(s.d. normal distribution) & &
\end{tabular}


(dummy: 1 if known, 0 otherwise)

Living wall/Green façade * aesthetically pleasing (dummy: 1 if

$1.011 * *(2.44)$

Model statistics:

$\begin{array}{lll}\text { Log-likelihood } & -1151.61 & -1141.42 \\ \text { Adjusted R2 } & 0.18 & 0.18 \\ \text { AIC value } & 2321 & 2304 \\ \text { Number of observations } & 1016 & 1016\end{array}$

\section{Notes:}

${ }^{1}$ Model A: attributes-only model

${ }^{2}$ Model B: individual-specific variables interacted with the policy options

Asterisks indicate significance: ${ }^{* *}$ for $<0.1 \%,{ }^{*}$ for $<1 \%$ and ${ }^{*}$ for $<5 \%$.

The estimated $\beta$-coefficents display the expected signs for the attributes, with positive utility associated with the three policy options and 'increase biodiversity' and negative utility associated with increasing cost and 'slowing biodiversity decline'. The three policy options are significant, suggesting that a green policy design is a significant determinant of choice associated over the no green policy scenario. The relative weighting of the policy options remains the same in Model A and Model B. Respondents place a higher level of utility on the living wall design, followed by the green façade, and lastly the alternative green policy. The parameters of the living wall and green façade are expected to reflect other benefits associated with green infrastructure, including aesthetic benefits.

Policy characteristics in both Model A and Model B are significant. The positive $\beta$-coefficients attached to the policy characteristic 'increase biodiversity' indicates that respondents are more likely to select a policy that enhanced biodiversity compared to a policy that maintains the current level of biodiversity. The negative utility associated with the policy characteristic 'slowing biodiversity decline' suggests that for the 'no green policy' option, respondents attach a lower level of utility to slowing biodiversity decline against a $£ 2$ payment than to the current decline without payment. However, the standard deviation of the random parameter is larger than its mean, which indicates that for a small proportion of the respondents the option to pay $f 2$ in order to slow down the decline in biodiversity loss has positive benefits. The negative $\beta$-coefficient for the cost parameter is as theoretically expected, and shows that the probability of selecting a policy decreases with an increase in policy cost. 
The lower AIC value of Model B compared to Model A indicates that accounting for interactions with attitudinal characteristics within the model results in a better fit. The $\beta$-coefficients attached to the respondent characteristics in Model B are significant determinants of choice, capturing further respondent heterogeneity in fixed effects, and reflect the probability of a household choosing one of the hypothetical scenarios relative to a no green policy option. ${ }^{4}$ In Model B, the attitudinal characteristic 'know biodiversity' is significant and captures respondent heterogeneity. The 'know green wall' variable was included in the model as a dummy variable taking the value one for respondents who stated to know what biodiversity was. These respondents attach a higher value to the three green policies. Furthermore, respondents who stated that they find green walls aesthetically pleasing are more likely to choose the living green wall or green façade than other respondents.

\subsection{Willingness to pay estimates}

Using equation (6), WTP values were estimated for both models (Table 7). Model A's marginal mean values for policy options range from $f 27.52$ per household per year for the alternative green policy, to $£ 34.10$ per household per year for the green façade, and $£ 37.88$ for the living wall. WTP based on Model B results are very similar at $£ 27.46$, $£ 38.23$ and $£ 38.08$ respectively, when using the sample mean of opinion on the aesthetics of green walls for the green façade and living wall estimates. The differences across these WTP estimates are not statistically significant. Model B results were used to obtain a value representative of the average household for three different scenarios. The first scenario is a living wall policy, the second a green façade and the final an alternative green policy; in all scenarios an increase in biodiversity was assumed. For all scenarios, the sample means for 'knowledge of biodiversity' of 0.76 , and 'aesthetically pleasing' of 0.91 was used.

Aggregating these scenarios WTP estimates across the entire region of Southampton, of approximately 91,217 households, results in an aggregated annual WTP of $f 5.2$ million for a living wall policy that increases biodiversity, and $£ 4.8$ million for a green façade (Table 8).

\footnotetext{
${ }^{4}$ To ensure this trend was not a result of the slight over-representation of the student population (Table 4), an additional model was run extending model B with a student dummy variable. The interaction of the student variable with policy options was insignificant. Results are available from the authors upon request.
} 

Table 7. Mean WTP values for policies and policy attributes

\begin{tabular}{|c|c|c|c|c|c|c|}
\hline \multirow{3}{*}{ Attribute } & \multicolumn{3}{|l|}{ Model $A^{1}$} & \multicolumn{3}{|c|}{ Model B ${ }^{2}$} \\
\hline & \multirow{2}{*}{$\begin{array}{l}\text { Mean } \\
\text { WTP }\end{array}$} & \multicolumn{2}{|l|}{$95 \% \mathrm{Cl}$} & \multirow{2}{*}{$\begin{array}{l}\text { Mean } \\
\text { WTP }\end{array}$} & \multicolumn{2}{|l|}{$95 \% \mathrm{Cl}$} \\
\hline & & LB & UB & & LB & UB \\
\hline \multicolumn{7}{|l|}{ Policy options: } \\
\hline Living Wall & 37.88 & 23.47 & 61.66 & 22.49 & 4.60 & 45.80 \\
\hline Green façade & 34.10 & 21.00 & 55.49 & 18.64 & 0.73 & 41.45 \\
\hline Alternative policy & 27.52 & 15.39 & 46.69 & 27.46 & 15.43 & 46.12 \\
\hline \multicolumn{7}{|l|}{ Policy characteristic: } \\
\hline Increase biodiversity & 18.44 & 13.75 & 25.84 & 9.86 & 1.24 & 19.14 \\
\hline Slow biodiversity decline & -109.63 & -52.78 & -9.12 & -50.14 & -102.11 & -10.98 \\
\hline \multicolumn{7}{|l|}{ Attitudinal characteristic } \\
\hline Know biodiversity & & & & 11.31 & 1.30 & 22.87 \\
\hline Aesthetically pleasing & & & & 17.14 & 3.64 & 33.43 \\
\hline
\end{tabular}

\section{Notes:}

Cl confidence interval, LB lower bound, UB upper bound, WTP willingness to pay.

${ }^{1}$ Modal A: attributes-only model

${ }^{2}$ Model B: individual-specific variables interacted with the policy options

Table 8. Aggregate WTP values for policy and policy attributes across Southampton (million $\mathrm{f}$ )

\begin{tabular}{llll}
\hline Attribute & Mean WTP & $95 \% \mathrm{Cl}$ & \\
\cline { 3 - 4 } & & LB & UB \\
\hline Living wall & 5.16 & 3.64 & 7.70 \\
Green façade & 4.81 & 3.36 & 7.15 \\
Alternative policy & 3.40 & 2.07 & 5.32 \\
\hline
\end{tabular}

Notes:

Cl confidence interval, LB lower bound, UB upper bound, WTP willingness to pay.

\subsection{Discussion}

\subsection{Public value of green walls}

All green policies increased utility significantly over the no-green policy scenario, which indicates a positive value associated with green infrastructure that increases biodiversity in Southampton. However, the difference between the welfare estimates is not significant. The statistical insignificant outcome may be due to lack of statistical 


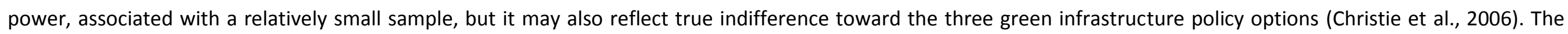

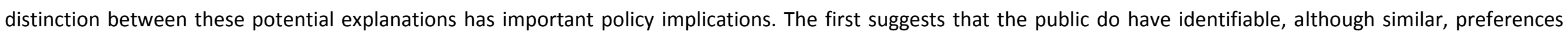

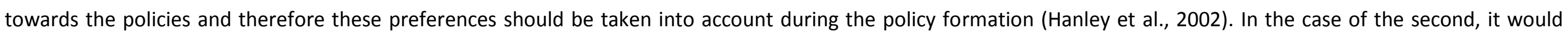

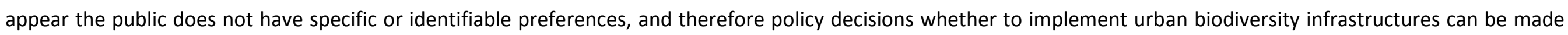

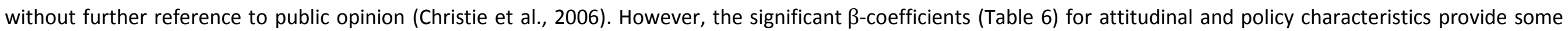

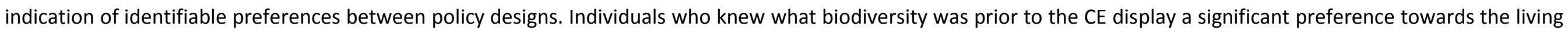

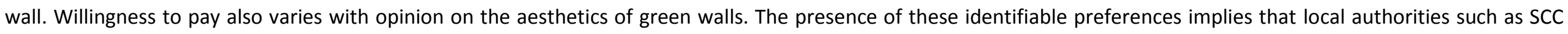

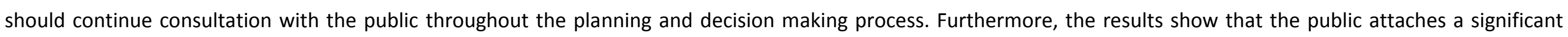

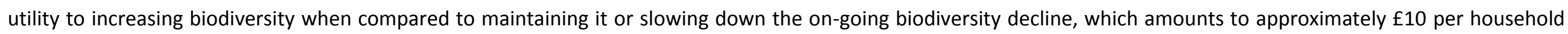

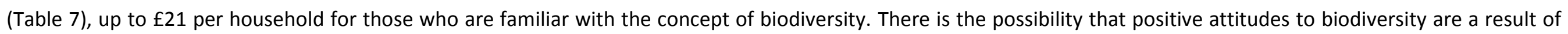

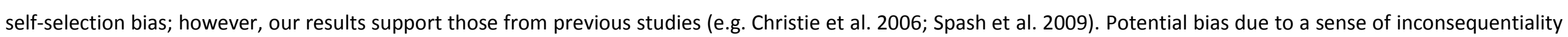
of the survey cannot be ruled out either as we did not include control questions to explore this aspect.

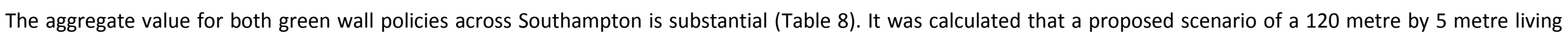

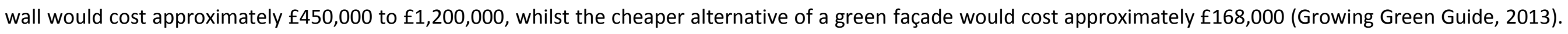

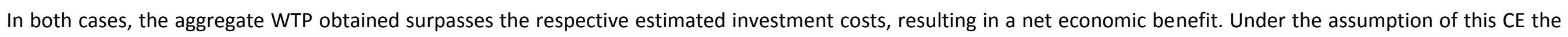

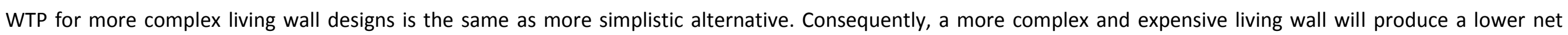

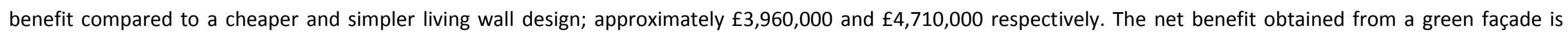


approximately $£ 4,642,000$. The greatest net benefit is obtained from a simple living wall design, it costs approximately $£ 470$ less per square meter to implement a green façade (Growing Green Guide, 2013). In our proposed scenario this equates to an additional cost of $£ 282,000$ for a $£ 68,000$ gain in net benefits.

Aggregate estimates (Table 8) are based on the assumption that all households in Southampton will benefit from the proposed green wall policy. Hence, we assume that the sample is representative for the total population of Southampton, also in terms of preferences towards the policies and frequency of visiting the city centre, and that WTP also contains non-use values, especially for biodiversity, that exist alongside use values associated with the appreciation of the aesthetic quality of green walls through visiting the centre or other ecosystem services benefits. Although this was not discussed in the survey, green walls aim to create ecological and biodiversity networks, which would mean that a green wall in the centre would have wider benefits. However, further research into the impacts of green walls are needed to assess biodiversity impacts at the wider urban scale. At the same time, we ignore the benefits enjoyed by visitors to Southampton and living outside the city boundaries who may benefit but not incur any cost. Overall, this study highlights how the use of CE to obtain monetary indicators can aid informed decision making and, in the case of local authorities, justify the allocation of limited public resources.

When utilising monetary values of biodiversity, local authorities must recognise that there is an ongoing debate regarding whether biodiversity, along with other elements of the environment, should, and reliably can, be assessed in monetary terms. We therefore recommend, especially at local level decision-making, to combine these stated preference valuation results with other decision-criteria, including public consultations such as citizen juries and non-monetary methods (Turner and Schaafsma 2015, Lienhoop et al. 2015).

In addition, the payment vehicle adopted for this study, a tax reallocation, is less conventional than raised taxes. Bergstrom et al. (2004), Nunes and Travisi (2008) and Swallow and McGonagle (2006) have found that the use of budget reallocation results in higher WTP payments compared to an increase in taxation, whereas results from 
Kontoleon et al. (2005) show that these payment vehicles result in statistically equivalent WTP estimates. Secondly, by bundling all public services into one public good, we cannot be certain of the exact services respondents considered to focus on and alter funding to when making their decision. This may affect the precision of the WTP estimates. However, this is not too dissimilar to the limitations associated with using a more conventional payment vehicle such as an increase in taxation (Morrison and MacDonald, 2011), and provisional results from Nunes and Travisi (2008) suggest that WTP from a budget reallocation does not depend upon the budget sources.

It should be further noted, that for simplicity our CE included only biodiversity impacts and costs as design elements, but the size and location of the proposed green policies was not specified. Through combining biodiversity benefits we have addressed limitations that cognitive burden can have on result validity (Hanley et al., 2002). However, as a result we are unable to disentangle values that individuals may attach to green infrastructure elements, such as a specific element of the design or aesthetics. The valuation of other green wall design elements or alternative green infrastructure options is an important area for future research. For example, our biodiversity attribute could be further specified. Previous valuation studies have used anthropogenic qualifications of biodiversity such as: "cuteness", "perceived rarity", and "charisma" in the CE design (Christie et al. 2006). It has been recognised that charismatic and flagship species attract significantly higher WTP (Christie et al., 2006; White et al., 2001). Future studies can be used to assess preferences towards green walls with 'beautiful, aesthetically pleasing' plants, designs that support wildlife, or other anthropogenic qualifications and their influence on the level of utility attached to green urban policies.

Welfare estimates obtained from this study strengthen the case for the implementation of green walls within cities. However, green walls are by no means the silver bullet for biodiversity enhancement in an urbanising world, and thus far attempts to increase biodiversity in cities has been narrowly focused at a project scale addressing only the immediate issues rather than the wider social and ecological patterns and processes (Hostetler et al., 2011). Green walls should be implemented as a technique to complement and create a valuable network of green spaces (Francis and Lorimer 2011). The adoption of a landscape scale management plan will ensure the stability of 
biodiversity but the integration of green walls in such plans represents a new frontier in applied ecology (Francis and Lorimer 2011). Further investigation into the strategic planning of green walls needs to be undertaken to ensure habitat heterogeneity is maximised at a landscape scale (Goddard et al., 2010).

\subsection{Conclusion}

To our knowledge, this paper presents the first study to use a choice experiment to value the public benefits associated with urban green walls and their contribution to urban biodiversity, and only the third empirical monetary valuation study of green walls after Veisten et al. (2012) and Perini and Rosasco (2013). On the basis of this study, which sampled a relatively small subset of the population, the Southampton general public attach a net economic benefit to the implementation of a green wall, within the city centre. However, green walls are only a single element of a green infrastructure network, and further research is recommended to ensure that their design and implementation complements existing green infrastructure to create a functional and stable network of biodiversity, at both a site and landscape scale, essential for the long-term provision of ecosystem services (Francis and Lorimer 2011; Goddard et al. 2010). The welfare estimates obtained are likely to be specific to Southampton; however, the methodology and broader policy implications of this research are applicable to other locations.

Despite recognised limitations of the use of monetary valuation studies for decision-making on biodiversity, this study demonstrates that valuing biodiversity provides benefits and using such information is more transparent in a policy and decision making context than the absence of it. Therefore, it is advisable that local authorities stimulate further research into public preferences using stated preference methods to value the benefits of green walls as well as other elements of green infrastructure in their area. Such efforts may help to increase the reliability and validity of WTP estimates, and thereby inform alternative financing instruments for urban green infrastructure. 


\section{Acknowledgements}

We would like to thank Lindsay McCulloch from Southampton City Council for proposing the research topic, and Julia Burnell, Alan Flinton and Abigail Leach for their help in collecting survey data.

\section{References}

Adamowicz, W., Louviere, J. J., Williams, M., 1994. Combining revealed and stated preference methods for valuing environmental amenities. Journal of Environmental Economics and Management, 26, 271-292. doi:10.1006/jeem.1994.1017

Angold, P. G., Sadler, J. P., Hill, M. O., Pullin, A., Rushton, S., Austin, K., Small, E., Wood, B., Wadsworth, R., Sanderson, R., Thompson, K., 2006. Biodiversity in urban habitat patches. Science of the Total Environment, 360(1), 196-204. doi:10.1016/j.scitotenv.2005.08.035

Atkinson, G., Bateman, I., Mourato, S., 2012. Recent advances in the valuation of ecosystem services and biodiversity. Oxford Rev. Econ. Policy, $28,22-47$. doi:10.1093/oxrep/grs007

Bartkowski, B., Lienhoop, N., Hansjürgens, B., 2015. Capturing the complexity of biodiversity: A critical review of economic valuation studies of biological diversity. Ecol. Econ., 113, 1-14. doi:10.1016/j.ecolecon.2015.02.023

Bergstrom, J.C., Boyle, K.J., Yabe, M., 2004. Trading taxes vs. paying taxes to value and finance public environmental goods. Environ. Resour. Econ., $28,533-549$. doi:10.1023/B:EARE.0000036779.58923.02

Bernath, K., Roschewitz, A., 2008. Recreational benefits of urban forests: Explaining visitors' willingness to pay in the context of the theory of planned behaviour. Environ. Manage., 89, 155-166. doi:10.1016/j.jenvman.2007.01.059

Bolund, P., Hunhammer, S., 1999. Ecosystem services in urban areas. Ecol. Econ., 29, 293-301.

Botzat, A., Fischer, L.K., Kowarik, I., 2016. Unexploited opportunities in understanding liveable and biodiverse cities: A review on urban biodiversity perception and valuation. Glob. Environ. Chang., 39, 220-233. doi:10.1016/j.gloenvcha.2016.04.008

Boxall, Peter, C., Adamowicz, W. L., Swait, J., Williams, M., Louviere, J., 1996. A comparison of the stated preference methods for environmental valuation. Ecological Economics, 18, 243-253. doi:0.1016/0921-8009(96)00039-0

Boyer, T., Polasky, S., 2004. Valuing Urban Wetlands: A review of non-market valuation studies. Wetlands, 24, 744-755. doi:10.1672/02775212(2004)024[0744:VUWARO]2.0.CO;2

Brander, L.M., Koetse, M.J., 2011. The value of urban open space: Meta-analyses of contingent valuation and hedonic pricing results. J. Environ. Manage., 92 , $2763-2773$. doi:10.1016/j.jenvman.2011.06.019

Broekx, S., Liekens, I., Peelaerts, W., De Nocker, L., Landuyt, D., Staes, J., Meire, P., Schaafsma, M., Van Reeth, W., Van den Kerckhove, O., Cerulus, T., 2013. A web 
application to support the quantification and valuation of ecosystem services. Environ. Impact Assess., 40, 65-74. doi:10.1016/j.eiar.2013.01.003

Carson, R.T., Groves, T. 2007. Incentive and informational properties of preference questions. Environmental and Resource Economics, 37(1), 181-210. doi:10.1007/s10640007-9124-5

Chen, W.Y., Jim, C.Y., 2010. Resident motivations and willingness-to-pay for urban biodiversity conservation in Guangzhou (China). Environ. Manage., 45(5), $1052-1064$. doi:10.1007/s00267-010-9478-2

Chiquet, C., Dover, J.W., Mitchell, P., 2013. Birds and the urban environment: The value of green walls. Urban Ecosyst., 16, 453-462. doi:10.1007/s11252-012-0277-9

Christie, M., Hanley, N., Warren, J., Hyde, T., Murphy, K., 2004. A valuation of biodiversity in the UK using choice experiments and contingent valuation. Paper Presented at the BIOECON Conference, Cambridge, UK.

Christie, M., Hanley, N., Warren, J., Murphy, K., Wright, R., Hyde, T., 2006. Valuing the diversity of biodiversity. Ecol. Econ., 58, $304-317$. doi:10.1016/j.ecolecon.2005.07.034

David Lock Associates, 2013. Southampton City Centre The Master Plan. [online] Available at: https://www.southampton.gov.uk/Images/City\%20Centre\%20Master\%20Plan_tcm63-365870.pdf [Accessed: 25 September 2016].

Department for Environment Food \& Rural Affairs (DEFRA), 2011. The Natural Choice: securing the value of nature. [online] Available at: https://www.gov.uk/government/uploads/system/uploads/attachment_data/file/228842/8082.pdf [Accessed: 25 September 2016].

Department for Communities and Local Government (DCLG), 2012. National Planning Policy Framework . [online] Available at: https://www.gov.uk/government/uploads/system/uploads/attachment_data/file/6077/2116950.pdf [Accessed: 25 September 2016].

Edwards, P.J., Abivardi, C., 1998. The value of biodiversity: Where ecology and economy blend. Biol. Conserv., 83, 239-246. doi:10.1016/S0006-3207(97)00141-9

European Commission, 2016. Descriptors defining levels in the European Qualifications Framework (EQF). [online] Available at: https://ec.europa.eu/ploteus/content/descriptors-page. [Accessed 28 August 2016].

European Commission, 2013. European Commission Building a Green Infrastructure for Europe Luxembourg: Publications Office of the European Union 2013. ISBN 978-9279-33428-3 doi:10.2779/54125

European Environment Agency (EEA), 2011. Green Infrastructure and Territorial Cohesion. The concept of green infrastructure and its integration into policies using monitoring systems. EEA Technical report No 13/2011. Luxembourg: Publications Office of the European Union.

Farnsworth, K.D., Adenuga, A.H., Groot, R.S. De, 2015. The complexity of biodiversity: A biological perspective on economic valuation. Ecol. Econ., 120, $350-354$. doi:10.1016/j.ecolecon.2015.10.003

Finlay, E., 2010. Green infrastructure to combat climate change, in: Northwest Climate Change Action Plan and GRaBS Project. Community Forest Northwest: Edinburgh.

Francis, R.A., Lorimer, J., 2011. Urban reconciliation ecology: The potential of living roofs and walls. J. Environ. Manage., 92, 1429-1437. doi:10.1016/j.jenvman.2011.01.012 
Fuller, R.A., Irvine, K.N., Devine-Wright, P., Warren, P.H., Gaston, K.J., 2007. Psychological benefits of greenspace increase with biodiversity. Biol. Lett., 3 , $390-394$. doi:10.1098/rsbl.2007.0149

Garrod, G.D., Willis, K.G., 1997. The non-use benefits of enhancing forest biodiversity: A contingent ranking study. Ecol. Econ., 21, 45-61. doi:10.1016/S09218009(96)00092-4

Goddard, M. A., Dougill, A.J., Benton, T.G., 2010. Scaling up from gardens: Biodiversity conservation in urban environments. Trends Ecol. Evol., $25,90-98$. doi:10.1016/j.tree.2009.07.016

Gómez-Baggethun, E., Barton, D.N., 2013. Classifying and valuing ecosystem services for urban planning. Ecol. Econ., 86, 235-245. doi:10.1016/j.ecolecon.2012.08.019

Growing Green Guide, 2013. Cost Considerations. [online] Available at: http://www.growinggreenguide.org/technical-guide/design-and-planning/cost [Accessed: 25 September 2016].

Hand, L., Barker, I., n.d. Southampton City Council's Biodiversity Action Plan - an update of the 1992 Nature Conservation Strategy. [online] Available at: http://www.chesselbay.org.uk/Biodiversity\%20Action\%20Plan_tcm46-220800.pdf [Accessed: 22 January 2017].

Hanley, N., Milne, J., 1996. Ethical beliefs and behaviour in contingent valuation surveys. J. Environ. Plan. Manag. 2, 255-272. doi:10.1080/09640569612598

Hanley, N., Wright, R.E., Koop, G., 2002. Modelling recreational demand using choice experiments: Climbing in Scotland. Environ. Resour. Econ., 22, 449-466. doi:10.1023/A:1016077425039

Hausman, J., McFadden, D., 1984. Specification tests for the multinomial logit model. Econometrica, 52, 1219-1240. doi:10.2307/1910997

Hostetler, M., Allen, W., Meurk, C., 2011. Conserving urban biodiversity? Creating green infrastructure is only the first step. Landsc. Urban Plan., 100, 369-371. doi:10.1016/j.landurbplan.2011.01.011

Hoyos, D., 2010. The state of the art of environmental valuation with discrete choice experiments. Ecol. Econ., 69, 1595-1603. doi:10.1016/j.ecolecon.2010.04.011

Hudson, D., Seah, L., Hite, D., Haab, T., 2004. Telephone presurveys, self-selection, and non-response bias to mail and Internet surveys in economic research. Applied Economics Letters, 11(4), 237-240. doi: 10.1080/13504850410001674876

Jones-Walters, L., Mulder, I., 2009. Valuing nature: The economics of biodiversity. J. Nat. Conserv., 17, 245-247. doi:10.1016/j.jnc.2009.06.001

Köhler, M., 2008. Green facades-a view back and some visions. Urban Ecosyst., 423-436. doi:10.1007/s11252-008-0063-x

Kontoleon, A., Yabe, M., Darby, L., 2005. Alternative payment vehicles in contingent valuation: the case of genetically modified foods. Munich Personal RePEc Archive, MPRA Paper No. 1827

Krinsky, I., Robb, A.L., 1986. On approximating the statistical properties of elasticities. Rev. Econ. Stat., 68, 715-719. doi:10.2307/1924536

Kwak, S., Yoo, S., Han, S., 2003. Estimating the public's value for urban forest in the Seoul metropolitan area of Korea: A contingent valuation study. Urban Stud., 40, 22072221. doi:10.1080/0042098032000123259 
Lancaster, K., 1966. A new approach to consumer theory. J. Polit. Econ., 74, 132-157.

Lienhoop, N., Bartkowski, B., Hansju, B., 2015. Environmental science \& policy informing biodiversity policy: The role of economic valuation, deliberative institutions and deliberative monetary valuation. Environ. Sci. Policy, 54, 522-532. doi:10.1016/j.envsci.2015.01.007

Lindsey, G., Knaap, G., 1999. Willingness to pay for urban greenway projects. Journal of the American Planning Association, 65, 297-313. doi:10.1080/01944369908976059

López-Mosquera, N., Sánchez, M., 2011. Emotional and satisfaction benefits to visitors as explanatory factors in the monetary valuation of environmental goods: An application to periurban green spaces. Land Use Policy, 28, 151-166. doi:10.1016/j.landusepol.2010.05.008

Louviere, J.J., Hensher, D.A., 1982. On the design and analysis of simulated choice or allocation experiments in travel choice modelling. Transp. Res. Rec., $11-17$.

Louviere, J.J., Hensher, D.A., Swait, J.D., 2000. Stated choice methods: analysis and application. J. Appl. Econom., 17, 701-704. doi:10.1002/jae.701

Louviere, J.J., Woodworth, G., 1983. Choice allocation consumer experiments: An approach aggregate data. Journal of Marketing Research. $20,350-367$.

Mace, G.M., Norris, K., Fitter, A.H., 2012. Biodiversity and ecosystem services: A multilayered relationship. Trends Ecol. Evol., 27, 19-25. doi:10.1016/j.tree.2011.08.006

Mallawaarachchi, T., Morrison, M.D., Blamey, R.K., 2006. Choice modelling to determine the significance of environmental amenity and production alternatives in the community value of peri-urban land: Sunshine Coast , Australia. Land Use Policy, 23, 323-332. doi:10.1016/j.landusepol.2004.11.004

Manski, C., 1977. The structure of random utility models. Theory Decis., 8, 229-254.

Manso, M., Castro-Gomes, J., 2015. Green wall systems: A review of their characteristics. Renew. Sustain. Energy Rev., 41, 863-871. doi:10.1016/j.rser.2014.07.203

Mcdonald, R.I., Kareiva, P., Forman, R.T.T., 2008. The implications of current and future urbanization for global protected areas and biodiversity conservation. Biol. Conserv., 141, 1695-1703. doi:10.1016/j.biocon.2008.04.025

McFadden, D., 1974. Conditional logit analysis of qualitative choice behaviour. Frontiers in Econometrics, ed. P. Zarembka. Academic Press: New York, $105-142$.

Morrison, M., MacDonald, D.H., 2011. A comparison of compensating surplus and budget reallocation with opportunity costs specified. Applied Economics, 43(30), 46774688. doi:10.1080/00036846.2010.493143

Morse-Jones, S., Bateman, I.J., Kontoleon, A., Ferrini, S., Burgess, N.D., Turner, R.K., 2012. Stated preferences for tropical wildlife conservation amongst distant beneficiaries: charisma, endemism, scope and substitution effects. Ecological Economics, 78, 9-18. doi: 10.1016/j.ecolecon.2011.11.002

Millennium Ecosystem Assessment (MEA), 2005. Ecosystems and human well-being, Ecosystems, Millennium Assessments. World Resources Institute. doi:10.1196/annals.1439.003

Natural England, 2013. Green Infrastructure - Valuation Tools Assessment. [online] Available at: http://publications.naturalengland.org.uk/publication/6264318517575680 [Accessed: 25 September 2016].

National Ecosystem Assessment (NEA), 2011. UK National Ecosystem Assessment Synthesis of the Key Findings. UNEP_WCMC: Cambridge. 
Nijkamp, P., Vindigni, G., Nunes, P.A.L.D., 2008. Economic valuation of biodiversity: A comparative study. Ecol. Econ., 67, 217-231. doi:10.1016/j.ecolecon.2008.03.003

Nunes, P.A.L.D., Travisi, C.M., 2009. Comparing tax and tax reallocation payments in financing rail noise abatement programmes: results from a stated choice valuation study in Italy. Environmental and Resource Economics, 43, 503-517. doi:10.1007/s10640-008-9243-7

Nunes, P.A.L.D., Van den Bergh, J.C.J.M., 2001. Economic valuation of biodiversity: Sense or nonsense? Ecol. Econ., 39, 203-222. doi:10.1016/S0921-8009(01)00233-6

Office for National Statistics (ONS), 2011. 2011 Census documents. [online]. Available at: https://www.southampton.gov.uk/council-democracy/councildata/statistics/2011-census-documents.aspx [Accessed: 25 September 2016].

Office for National Statistics (ONS), 2013. Population and Migration: How densely populated is your area. [online]. Available at: http://www.neighbourhood.statistics.gov.uk/HTMLDocs/dvc134_c/index.html [Accessed: 25 September 2015].

Office for National Statistics (ONS), 2014. Labour Market Profile - Southampton. [online] Available at: https://www.nomisweb.co.uk/reports/Imp/la/1946157287/report.aspx?pc=So173Sj [Accessed: 25 September 2016].

Pascual, U., Muradian, R., Gómez-Baggethun, E., Armsworth, P., Brander, L., Cornelissen, H., Farley, J., Loomes, J., Martinez-López, B., Pearson, L., Perrings, C., Polasky, S., Verma, M., 2010, 'Valuation of Ecosystems Services: Methodology and Challenges', in P. Kumar (ed.), The Economics of Ecosystems and Biodiversity: Ecological and Economic Foundations, Earthscan: London.

Pascal, U., Muradian, R., Gómez-Baggethun, E., Armsworth, P., Brander, L., Cornelissen, H., Farley, J., Loomes, J., Martinez-López, B., Pearson, L. and Perrings, C., 2009. Report to review of the economics of ecosystems and biodiversity. European Commission/UNEP/BMU-Germany.

Perini, K., Rosasco, P., 2013. Cost-benefit analysis for green façades and living wall systems. Build. Environ., 70, 110-121. doi:10.1016/j.buildenv.2013.08.012

Potschin, M., Young, R.H., Fish, R., Turner, R.K., Watson, R., Potschin, M., Young, R.H., Fish, R., Turner, R.K., Luck, G., Hauck, J., Rounsevell, M., Harrison, P.A., Baggethun, E.G., Barton, D.N., Berry, P., Dunford, R., Harrison, P.A., Turner, R.K., Turner, R.K., Turner, R.K., 2016. Routledge Handbook of Ecosystem Services. Routledge.

Partnership for Urban South Hampshire (PUSH), 2010. Green Infrastructure Strategy for the Partnership for Urban South Hampshire. [online] Available at: http://www.push.gov.uk/push_gi_strategy_adopted_june_10-3.pdf [Accessed: 25 September 2016].

Ready, R.C., Navrud, S., Dubourg, W.R. 2001. How do respondents with uncertain willingness to pay answer contingent valuation questions?. Land Economics, 77, 315-326. doi:10.2307/3147126

Rosenzweig, M. L., 2003. Reconciliation ecology and the future of species diversity. Oryx, 37(2), 194-205. doi: 10.1017/\$0030605303000371

Rudd, M.A., Andres, S., Kilfoil, M., Andres, S., 2016. Non-use economic values for little-known aquatic species at risk: Comparing choice experiment results from surveys focused on species, guilds, and ecosystems. Environ. Manage., 58, 476-490. doi:10.1007/s00267-016-0716-0

Shwartz, A., Turbé, A., Simon, L., Julliard, R., 2014. Enhancing urban biodiversity and its influence on city-dwellers: an experiment. Biological Conservation, 171, 82-90. 
Southampton City Council (SCC), 2008. Strategy Technical Document: Green spaces great places. [online] Available at:

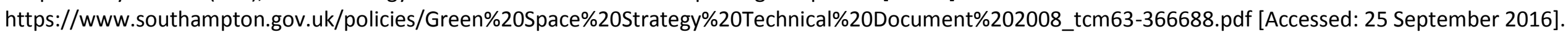

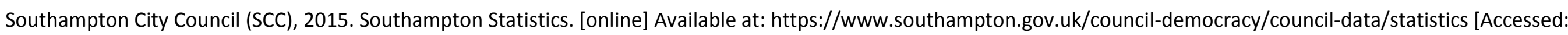
25 September 2016].

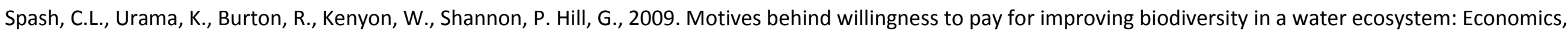
ethics and social psychology. Ecological Economics, 68(4), 955-964. doi:10.1016/j.ecolecon.2006.09.013

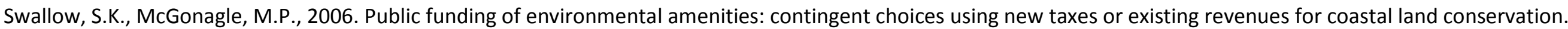
Land Econ., 82, 56-67. doi:10.3368/le.82.1.56

Thurstone, L., 1994. A law of comparative judgement. Psychol. Rev., 101, 266-270.

Train, K. E., 1999. Halton sequences for mixed logit. Working Paper 1-18, Department of Economics, University of California, Berkeley.

Train, K. E., 2003. Discrete Choice Methods with Simulation. Cambridge University Press: Cambridge.

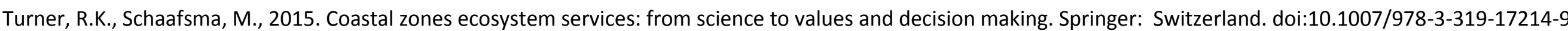

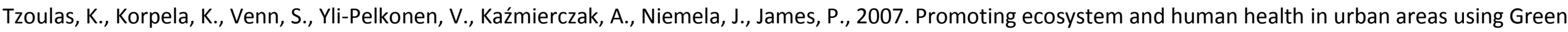
Infrastructure: A literature review. Landsc. Urban Plan., 81, 167-178. doi:10.1016/j.landurbplan.2007.02.001

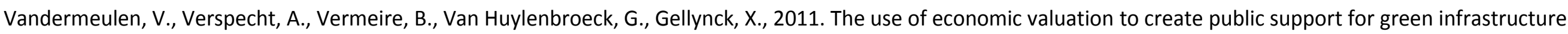
investments in urban areas. Landsc. Urban Plan., 103, 198-206. doi:10.1016/j.landurbplan.2011.07.010

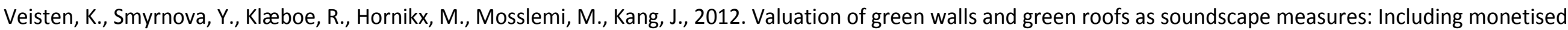

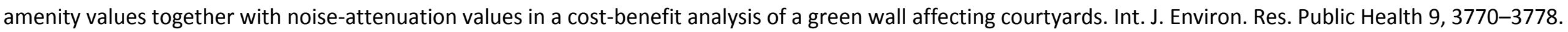
doi:10.3390/ijerph9113770

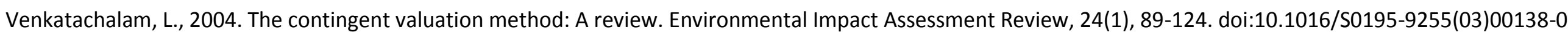

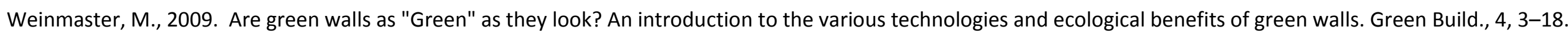
doi:10.3992/jgb.4.4.3

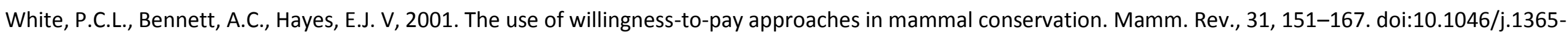
2907.2001.00083.x

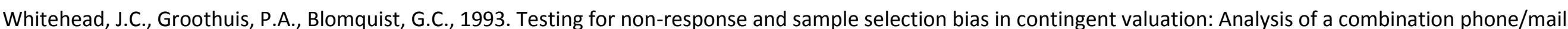
survey. Economics Letters, 41(2), 215-220. 



\section{SECTION 1: Green Walls}

\section{Do you know what a green wall is?}

\begin{tabular}{l|l} 
& Yes \\
\hline & No \\
\hline & Not Sur
\end{tabular}

\section{INFORMATION BOX: Green Walls}

A green wall is a wall partially or completely covered in plants. This research will focus on the $\underline{\mathbf{2}}$ types of green walls:

1. Green facades - a made up of one or two climbing plants growing on a vertical surface.

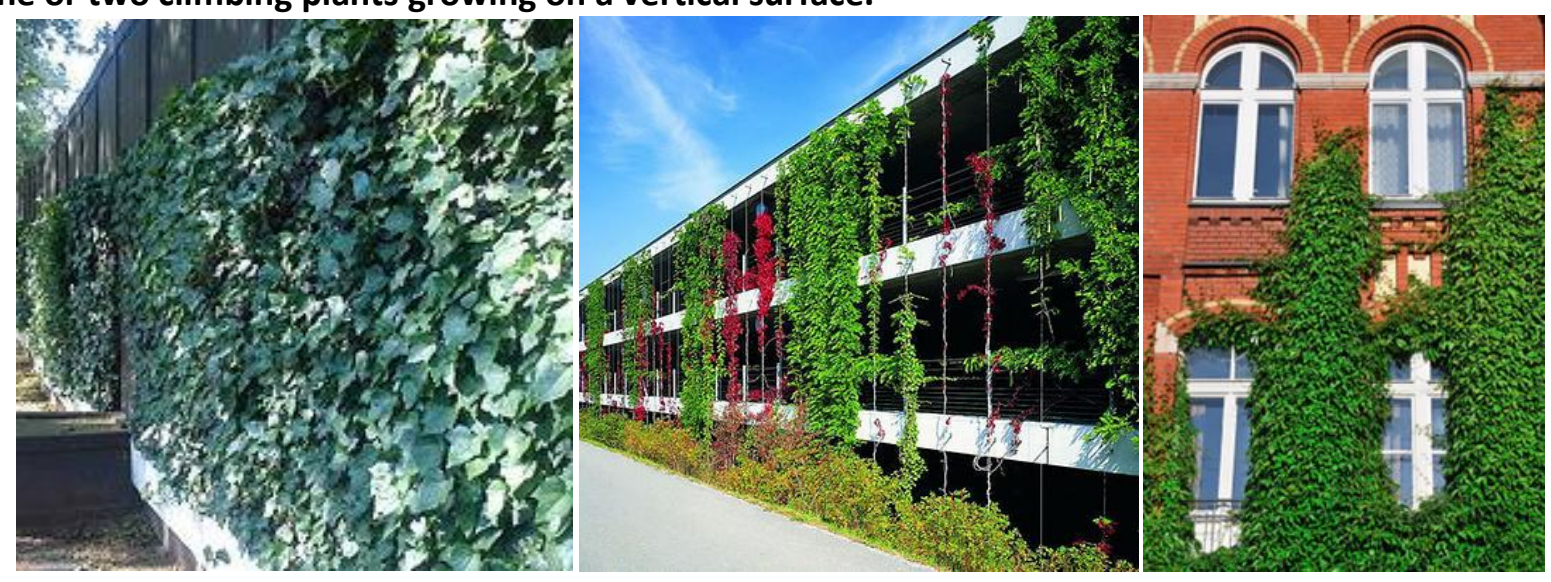

2. Living walls - walls contain a soil and so can support a large number different plants

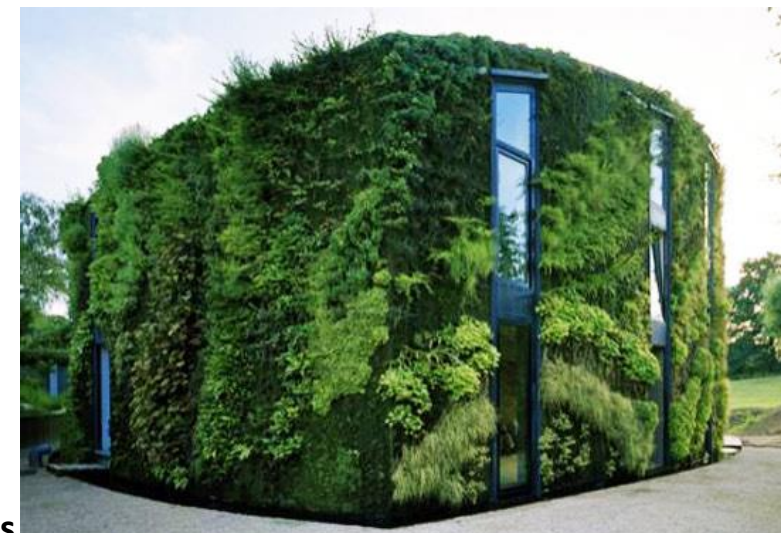




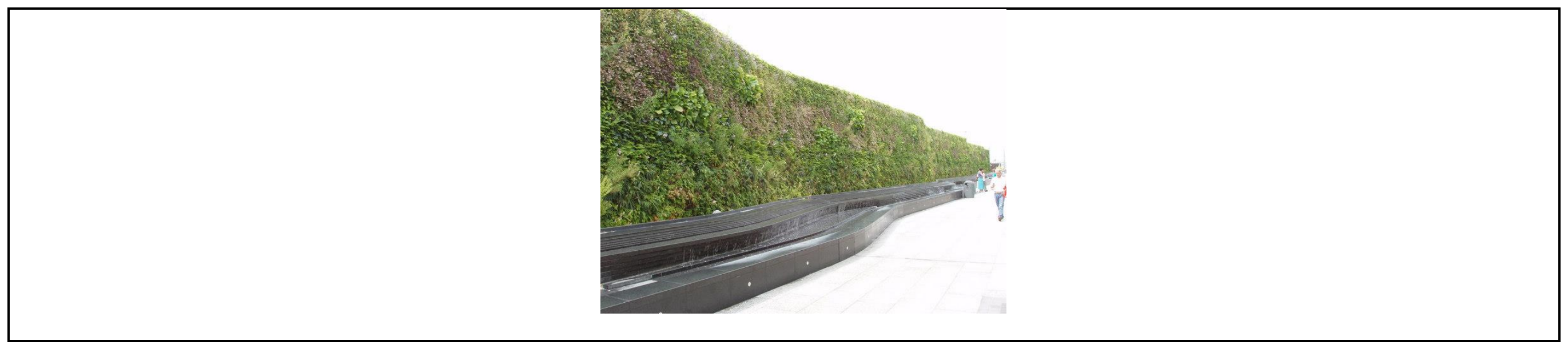

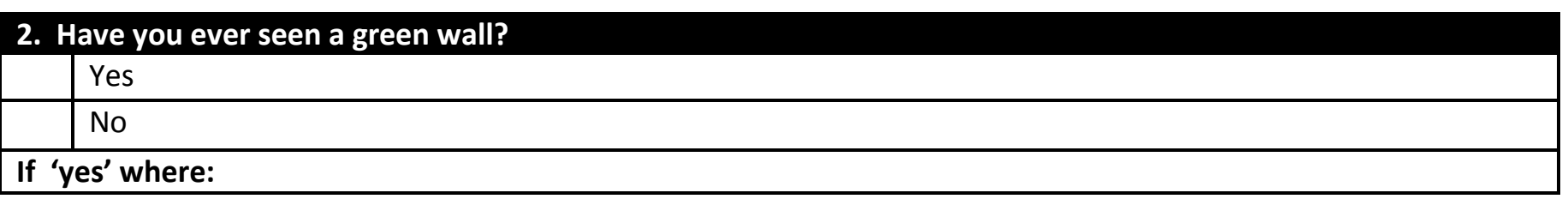

3. Are you aware of any green walls in your local area?
\begin{tabular}{|l|l|}
\hline & Yes \\
\hline & No \\
\hline If 'yes' where: \\
\hline
\end{tabular}

\begin{tabular}{|c|c|}
\hline Yes & Further comments (if made): \\
\hline No & \\
\hline Unsure / Don't know & \\
\hline
\end{tabular}

\begin{tabular}{|c|c|}
\hline 5. Out of the following wall designs which do you prefer? (refer to images on previous page) \\
Green facade & Living Wall \\
$\square$ & $\square$ \\
\hline
\end{tabular}

6. Are you aware of any benefits green walls can provide? If so what benefits?

$$
\text { Yes }
$$




\section{Green Walls provide benefits to biodiversity, are you familiar with the term biodiversity?}

Yes

No - please refer to information box

Unsure/ Don't know - please refer to information box

\section{INFORMATION BOX: Benefits to Biodiversity}

- Among other benefits green walls can increase biodiversity

- Biodiversity is a broad term that is commonly used to describe the biological variety in an environment, indicated by the number of DIFFERENT species of plants and animals and habitats present.

- The more species and habitats the higher the level of biodiversity.

- A high level of biodiversity is proven to benefit human health.

Current trends suggest that urban biodiversity is declining and will continue to decline unless policies are put in place to stop these declines.

Green walls are one possible policy that can help stop this decline.

The next section of this questionnaire will take your opinions on such policies into consideration

\section{Would you like to see more green walls within your local area?}

\begin{tabular}{|l|l|}
\hline Yes & \multirow{2}{*}{ Further comments (if made): } \\
\hline No & \\
\hline Unsure/ Don't know & \\
\hline
\end{tabular}

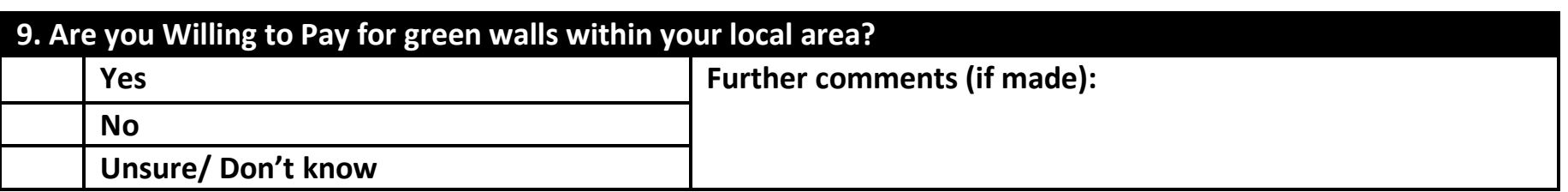





\section{SECTION 2: Policy Choice}

\section{INFORMATION BOX: Policy Choice}

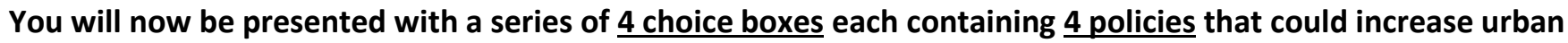
biodiversity:

1. Living Wall - more than $\mathbf{3}$ species of plants to be located in the city centre

2. Green Facade - 1 or 2 species of climbing plants to be located in the city centre

3. Alternative Green Policy - investing money into increasing biodiversity of existing local parks and green spaces, such as Southampton Common

4. No green Policy

Each policy has different effect on biodiversity and varying cost.

The cost should be considered as an annual payment from your council tax (no additional payment required).

When making your decision please consider the impact this will have on services provided by the SCC.

You must select only one policy.

Scenario 1:

\section{Policy Description:}

Biodiversity

Monthly cost

Check only one box:

Scenario 2:

Policy Description:

Biodiversity

Cost

Check only one box:

Scenario 3:

Policy Description:

Living Wall

Green Facade

Green Facade

Living Wall

Increase level of urban biodiversity

f10

reen Facade

Increase level of urban biodiversity

f25

$\square$

$\square$

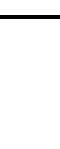

Biodiversity

Maintain urban biodiversity at current level

Cost
Maintain urban biodiversity at current level f2 f2

\section{Alternative Green Policy}

Increase level of urban biodiversity £10

$\square$

$\square$

$\square$

Alternative Green Policy

Increase level of urban biodiversity f25

No Green Policy

Slow the decline of urban biodiversity

£2 Alternative Green Policy

No Green Policy

Allow urban biodiversity to decline 


\section{Check only one box:}

Scenario 4:

\section{Policy Description:}

Living Wall

Green Facade

Alternative Green Policy

No Green Policy

Biodiversity

Cost

Increase level of urban

Increase level of urban biodiversity $£ 25$ $£ 10$ current level £10

Allow urban biodiversity to decline

Check only one box:

25

$\square$ £0

\section{SECTION 3: Socio-Economic Information}

\begin{tabular}{|c|c|c|}
\hline 1. Age & & Gender \\
\hline $15-24$ & $45-54$ & Male \\
\hline $25-34$ & $55-64$ & Female \\
\hline $35-44$ & $65+$ & \\
\hline
\end{tabular}

3.

\section{Household size}

4. Number of Children per household

\begin{tabular}{|l|l|l|l|}
\hline 1 & & 4 \\
\hline & 2 & & 5 \\
\hline & 3 & & $6+$ \\
\hline
\end{tabular}

5. Highest Level of Education

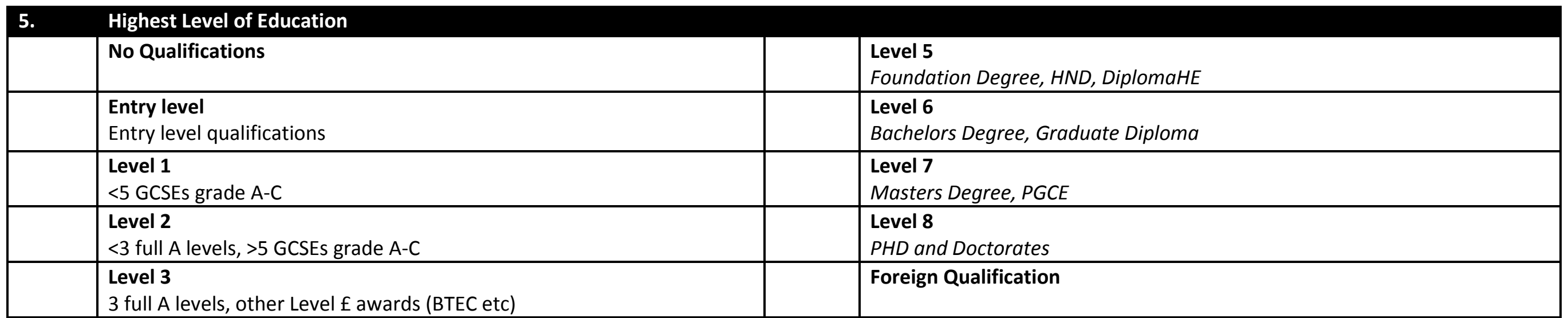




\begin{tabular}{|l|l|l|l|}
\hline & $\begin{array}{l}\text { Level 4 } \\
\text { Certificate of Higher Education }\end{array}$ & & Unknown: Please state \\
\hline
\end{tabular}

\section{Occupation}

Please State:

\begin{tabular}{|l|l|}
\hline 8. & Annual Household Income \\
\hline & Under $£ 20,000$ a year \\
\hline & Between $£ 20,000-£ 40,000$ a year \\
\hline & Between $£ 40,000-£ 60,000$ a year \\
\hline & Between $£ 60,000-£ 80,000$ a year \\
\hline & Between $£ 80,000-£ 100,000$ a year \\
\hline & Over $£ 100,000$ a year \\
\hline
\end{tabular}




\section{SECTION 1: Green Walls}

\section{INFORMATION BOX: Green Walls}

A green wall is a wall partially or completely covered in plants. This research will focus on the $\underline{\mathbf{2}}$ types of green walls:

3. Green facades - a made up of one or two climbing plants growing on a vertical surface.

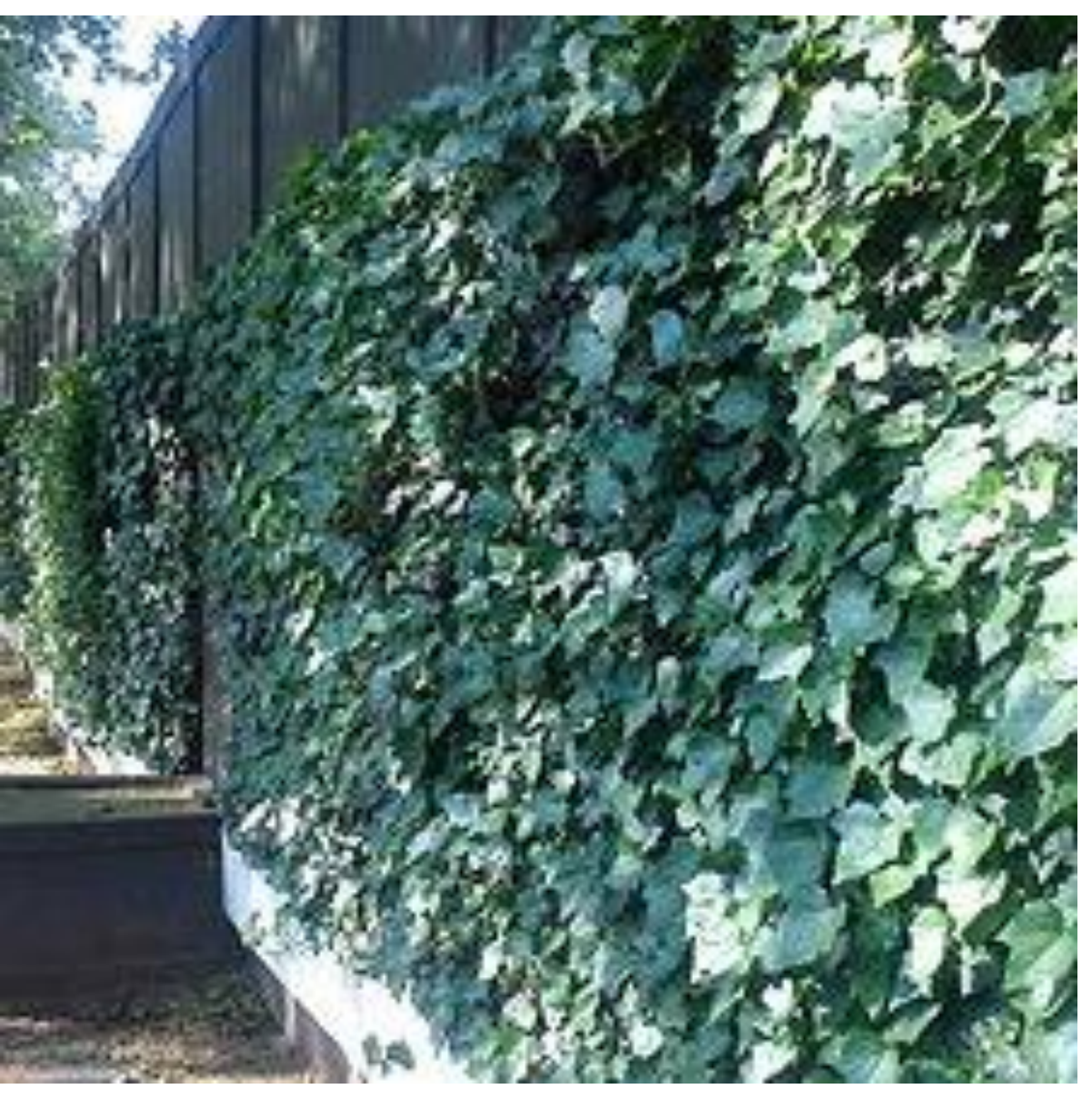

Green Façade example 1

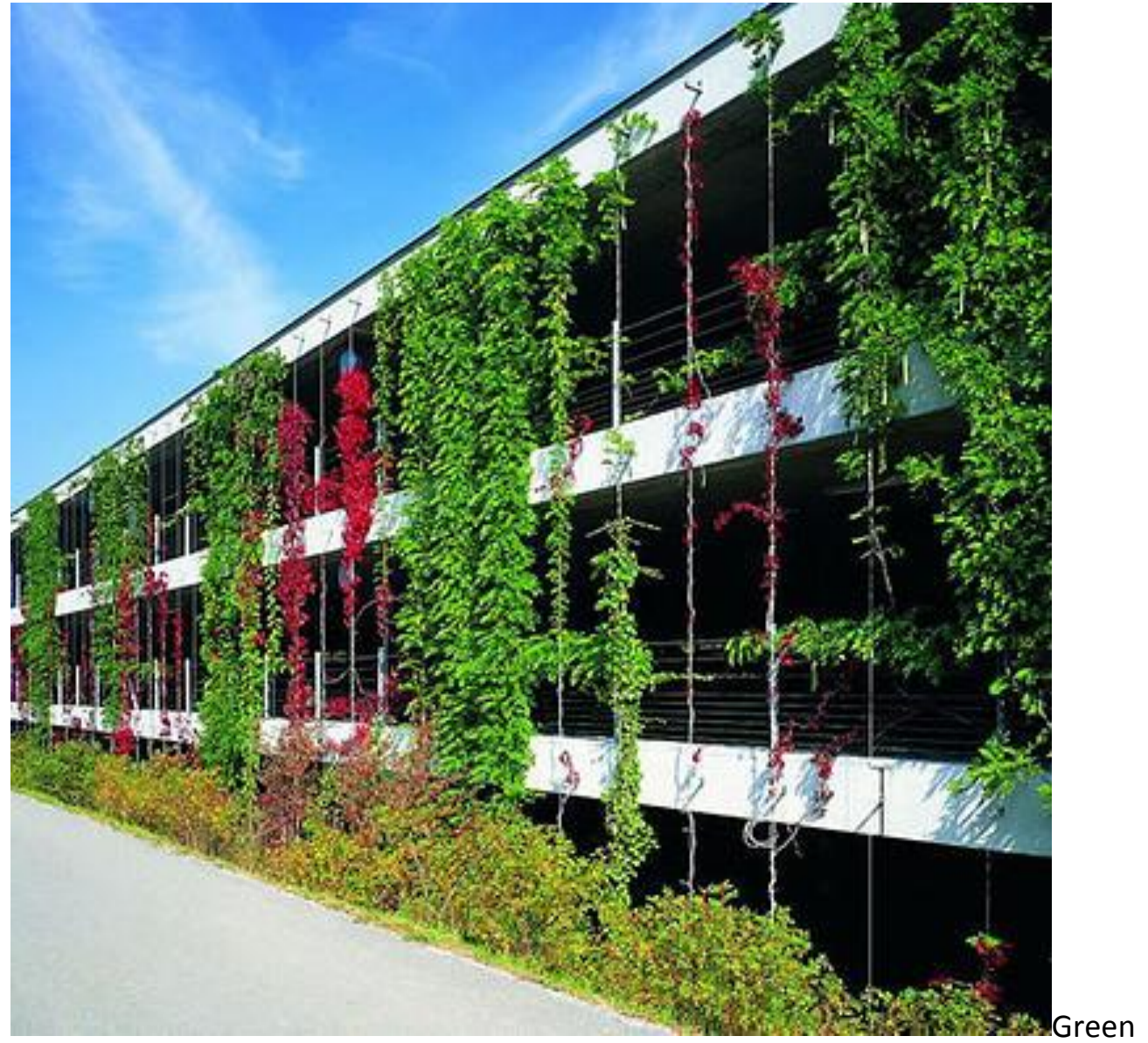

façade example 2 


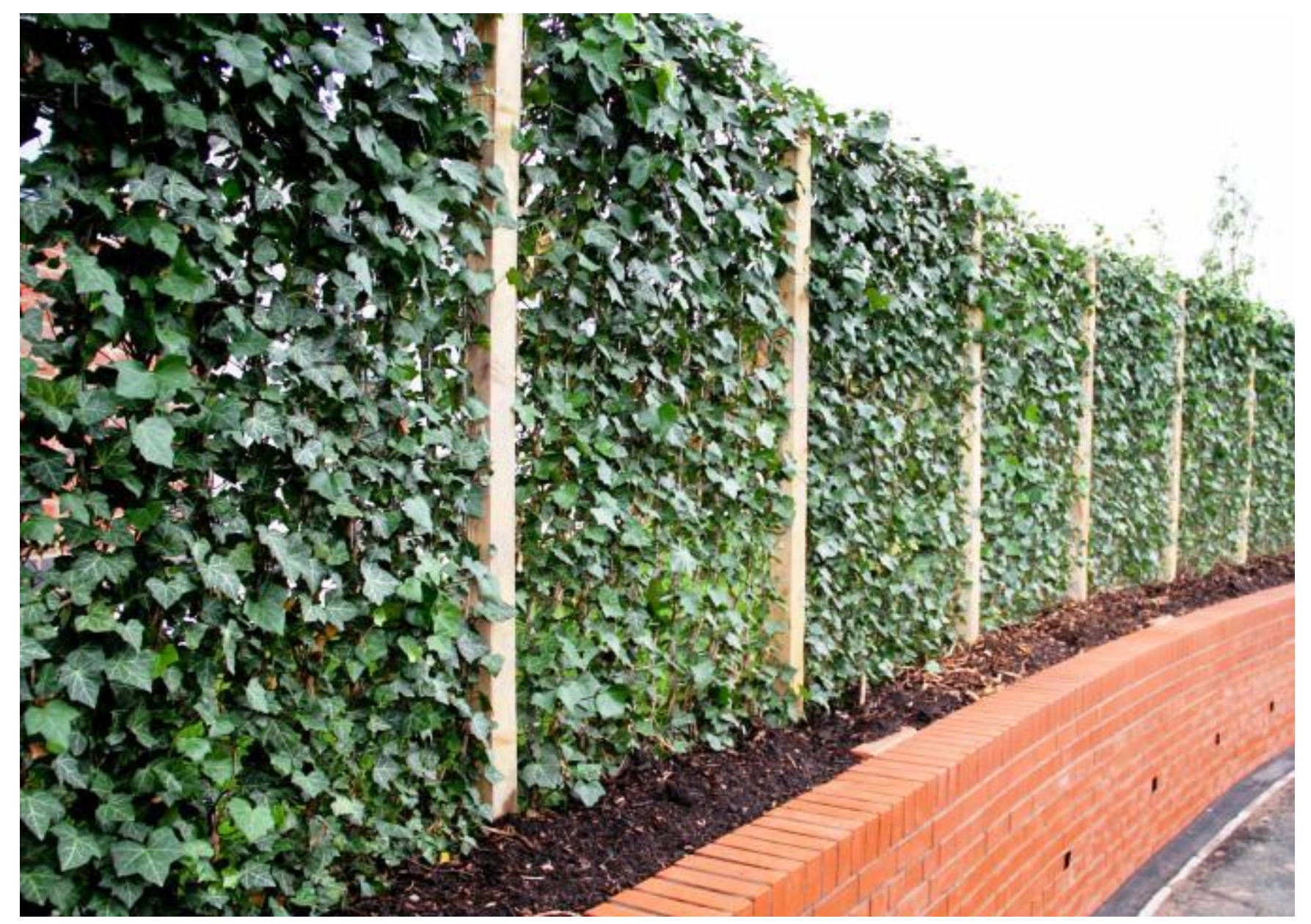

Green façade example 3 


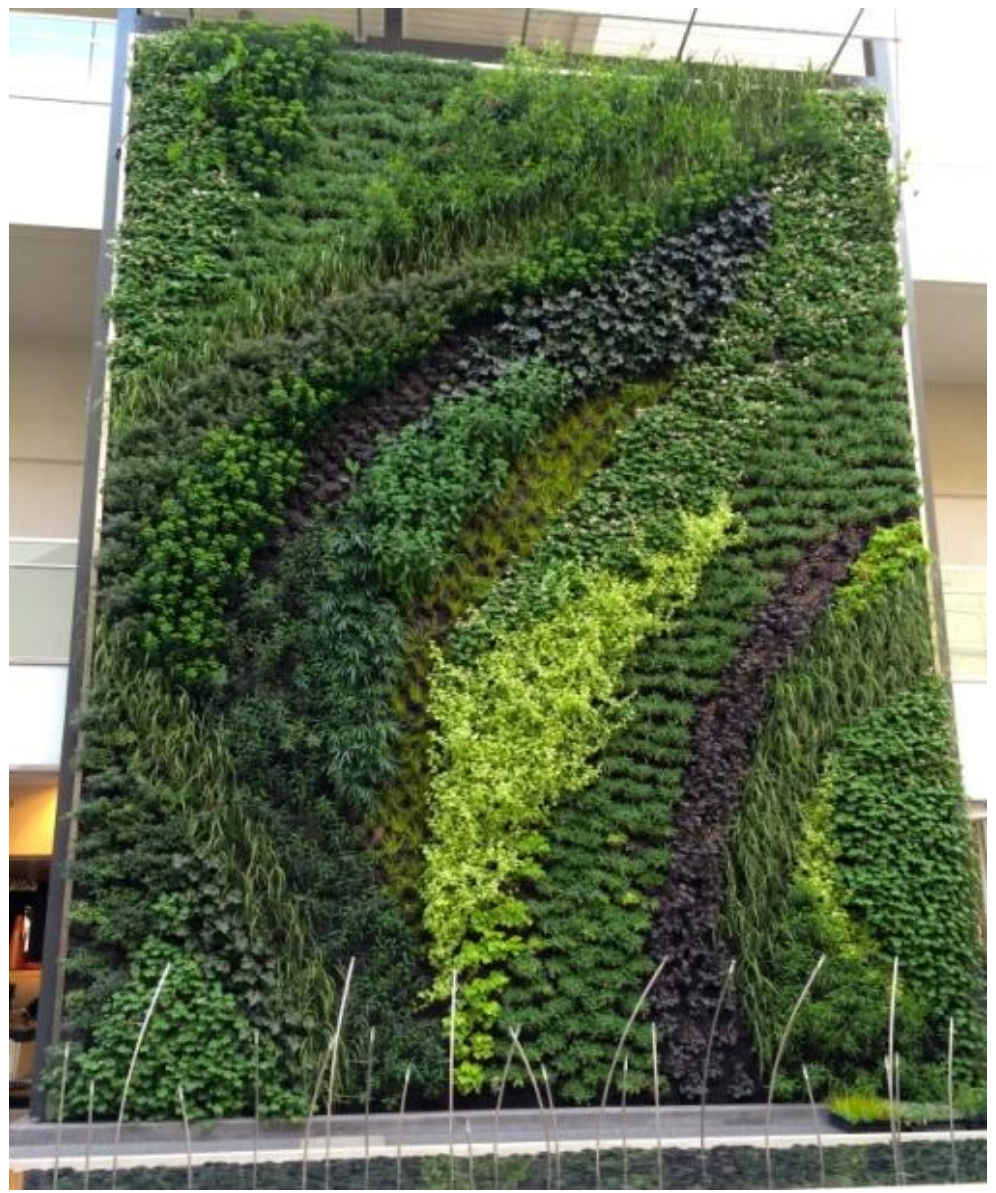

Living wall example 1

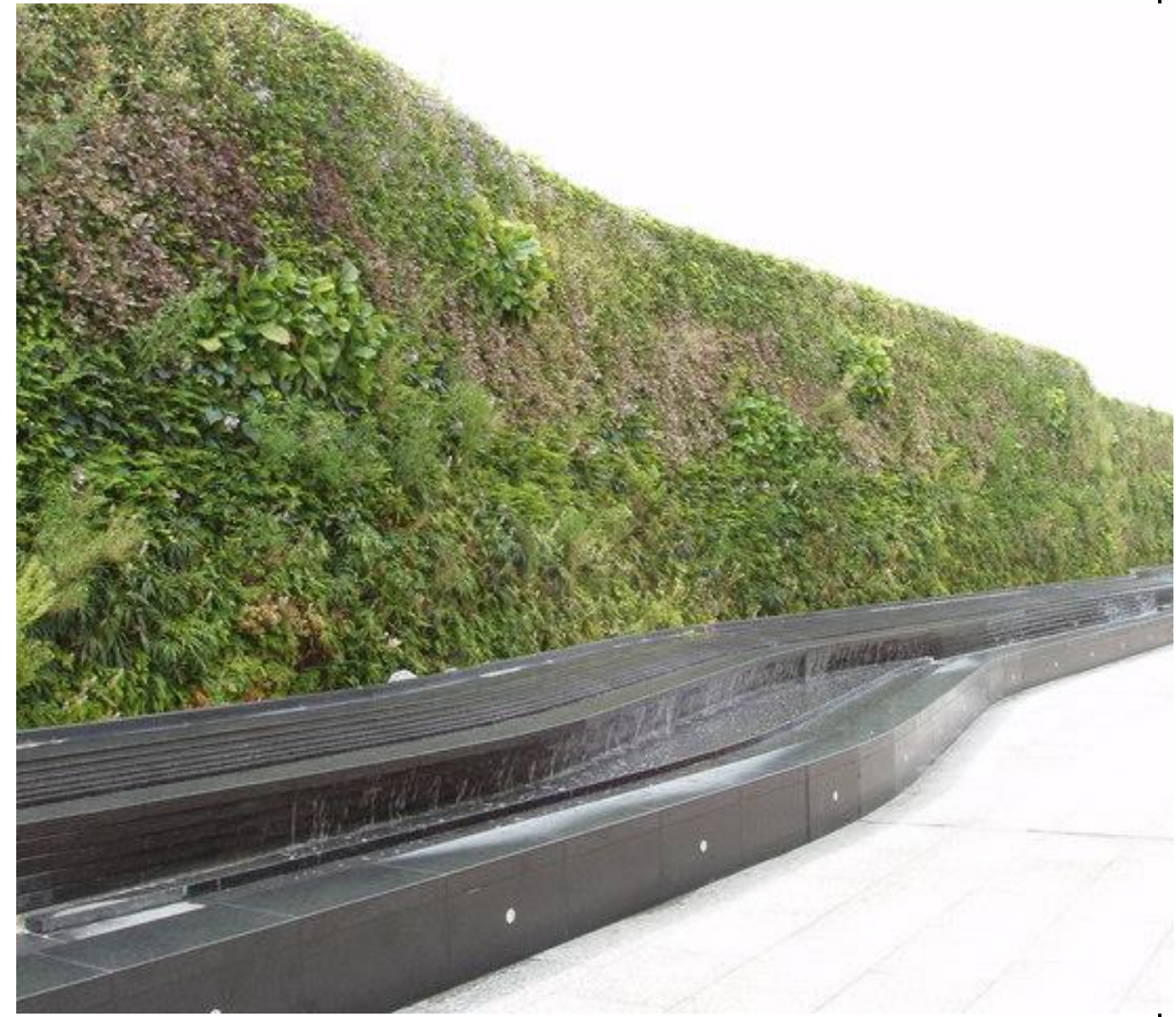

Living wall example 2 


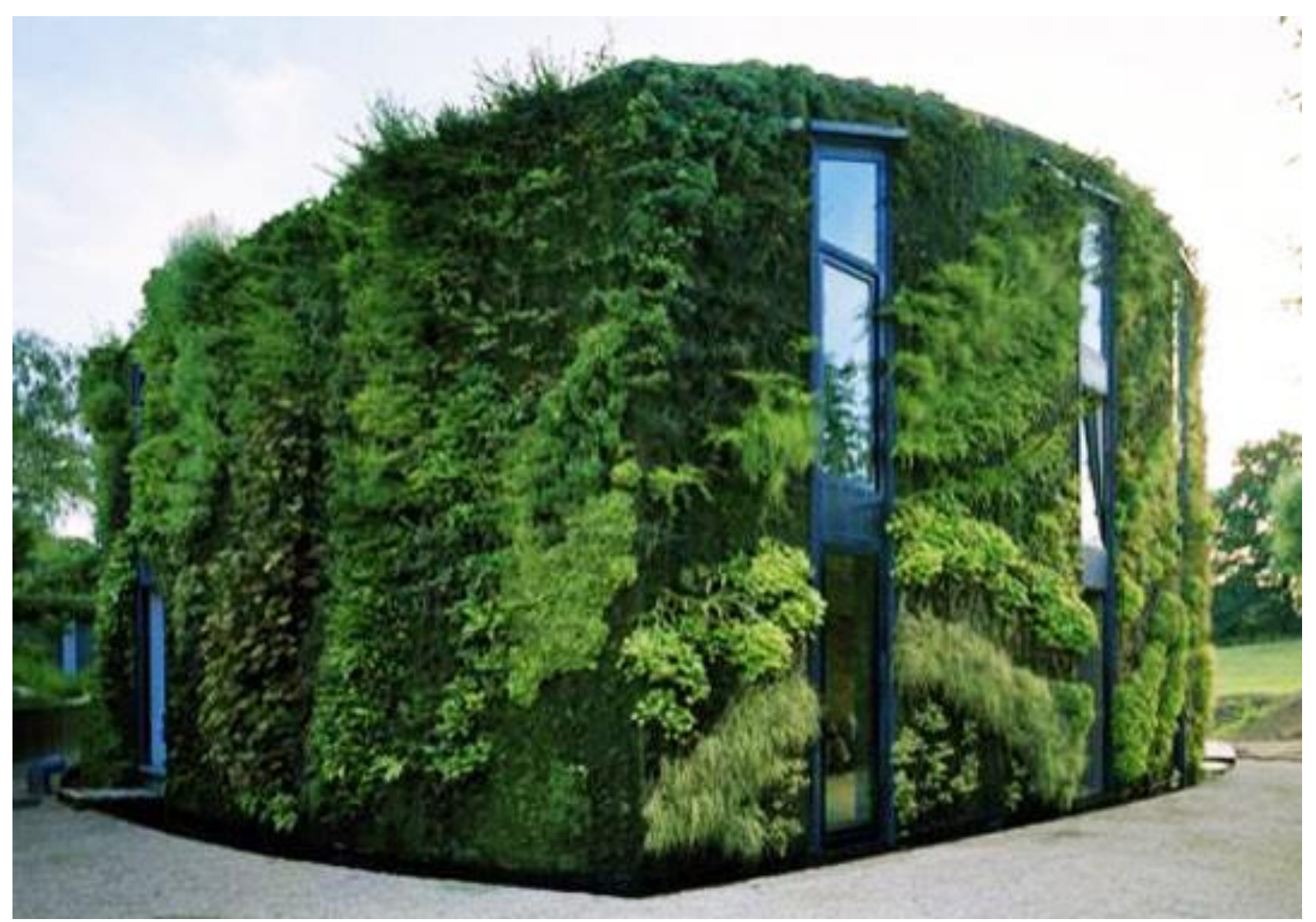

Living wall example 3 


\section{INFORMATION BOX: Benefits to Biodiversity}

- Among other benefits green walls can increase biodiversity

- Biodiversity is a broad term that is commonly used to describe the biological variety in an environment, indicated by the number of DIFFERENT species of plants and animals and habitats present.

- The more species and habitats the higher the level of biodiversity.

- A high level of biodiversity is proven to benefit human health.

Current trends suggest that urban biodiversity is declining and will continue to decline unless policies are put in place to stop these declines.

Green walls are one possible policy that can help stop this decline.

The next section of this questionnaire will take your opinions on such policies into consideration

\section{SECTION 2: Policy Choice}

\section{INFORMATION BOX: Policy Choice}

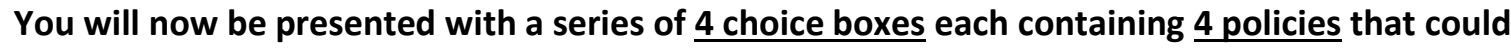
increase urban biodiversity:

5. Living Wall - more than $\underline{3}$ species of plants to be located in the city centre

6. Green Facade $-\underline{1}$ or $\mathbf{2}$ species of climbing plants to be located in the city centre

7. Alternative Green Policy - investing money into increasing biodiversity of existing local parks and green spaces, such as Southampton Common

8. No green Policy

Each policy has different effect on biodiversity and varying cost.

The cost should be considered as an annual payment from your council tax.

This payment is a reallocation of funding from services provided by the SCC to fund a Green Wall or Alternative Green Policy. No additional payment to your council tax is required.

You must select only one policy.

\section{INFORMATION BOX: SCC Services}

When making your decision please consider the impact this will have on services provided by the SCC. Example services delivered by the SCC include:

1. Communities, Culture and Leisure:

- Southampton City Art Gallery

- CCTV

- Community centres

2. Education and Children's Social Care:

- Libraries

3. Environment and Transport:

- Allotments

- Bin/waste collection

- Flood management

- Pest control

- Roadwork/road maintenance

- Snow clearance

- Street cleaning

4. Finance: 


\section{- Money advice}

5. Health and Adult Social Care:

- Drug and alcohol recovery services

6. Housing and Sustainability:

- Affordable housing 